\title{
A fundação do Partido Comunista do Brasil
}

\section{The founding of the communist Party of Brazil}

\begin{abstract}
RoUl K. M. CərilOO*
O primeiro grande passo a ser dado [...] é a constituição dos operários em partido político independente, não importando como, desde que ele seja um partido operário distinto. [...] Que o primeiro programa desse partido ainda seja confuso e muito deficiente [..., isto é um mal inevitável, mas, também, transitório. As massas devem ter tempo e oportunidade de desenvolver-se, e só terão essa oportunidade se têm um movimento próprio, no qual serão impulsionadas pelos seus próprios erros, tornando-se sábias às suas próprias custas.

Friedrich Engels, "Carta a Sorge (29/II/I886)" (tradução nossa)

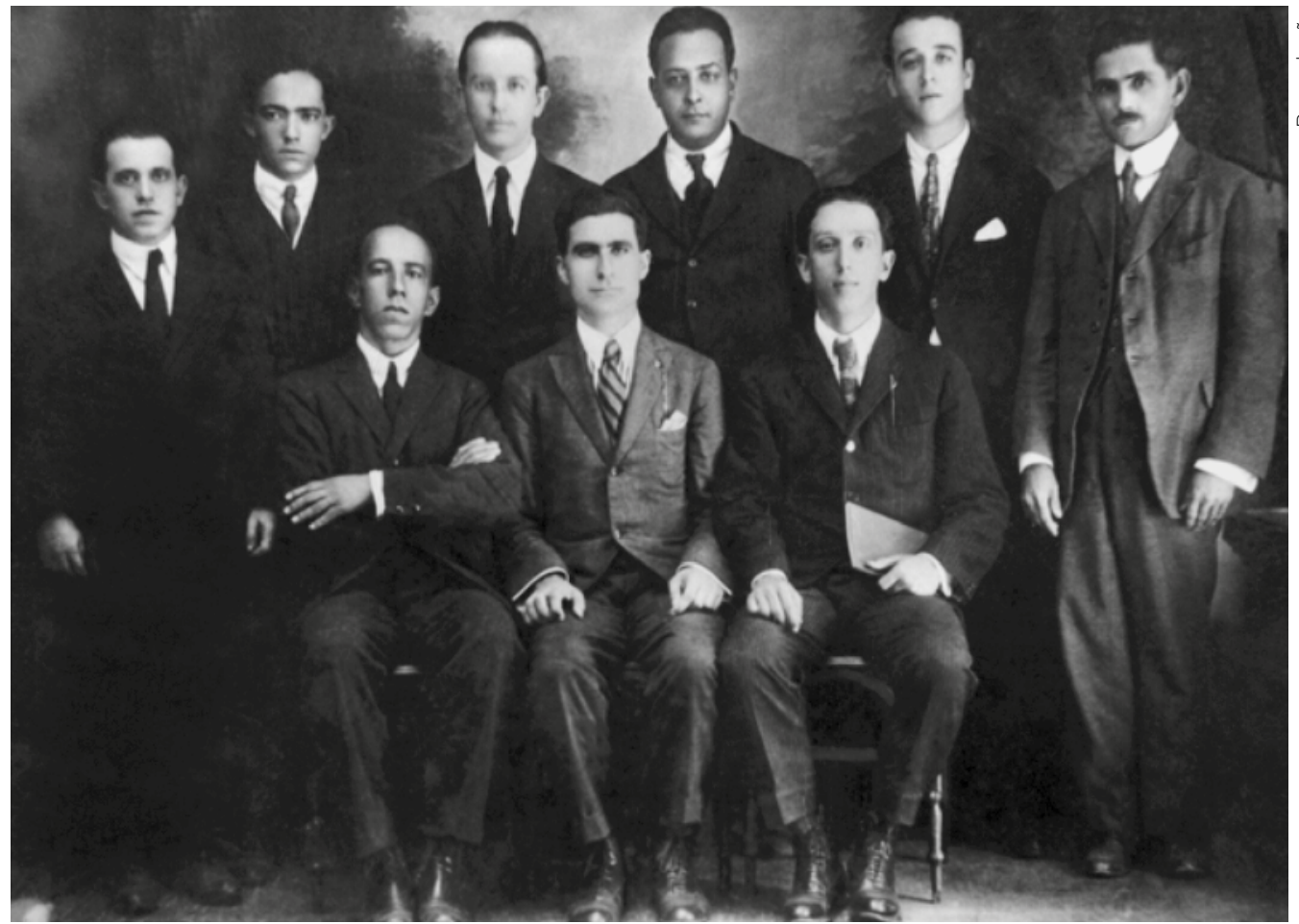

Delegados presentes no congresso de fundação do Partido Comunista do Brasil, realizado entre 25 e 27 de março de 1922, nas cidades do Rio de Janeiro e Niterói (RJ) 


\section{RESUMO}

O objetivo central deste estudo é reconstituir o processo de formação do Partido Comunista do Brasil — desde os primórdios do movimento operário brasileiro até os seus primeiros anos de vida - identificando as causas do seu surgimento e as razões que viabilizaram a sua permanência até hoje, apesar das incontáveis tentativas (externas e internas) de liquidá-lo. A principal hipótese de trabalho é que o surgimento do Partido Comunista do Brasil não foi algo artificial, fruto da "vontade" de alguns indivíduos ou "uma ideia trazida de fora", "criação da Internacional Comunista", mas refletiu uma necessidade objetiva, decorrente da evolução social do Brasil — que em 1922 se encontrava em um momento de rupturas - e do desenvolvimento de sua classe operária. Na visão de Marx, correspondeu à conversão do proletariado de "classe em si" para "classe para si". O método de análise utilizado foi o materialismo histórico e dialético. A conclusão que emerge deste estudo é que a continuidade do Partido Comunista do Brasil - apesar de todas as perseguições sofridas - expressa a existência objetiva de espaço político para um projeto de transformação radical e revolucionária da sociedade capitalista brasileira, distinto dos projetos reformistas da burguesia e da pequena burguesia.

Palavras-chave: Partido Comunista do Brasil. Marxismo. Classe operária.

\section{ABSTRACT}

The aim of this study is to reconstitute the founding of the Communist Party of Brazil - from the beginnings of Brazilian labor movement to its first years of life - identifying the causes that led to its emergence and the reasons that made it viable up to nowadays, despite countless attempts (external and internal) to liquidate it. The main working hypothesis is that the emergence of the Communist Party of Brazil was not something artificial, the simple result of one's "will" or "an idea brought from outside", "creation of the Communist International". Instead, it reflected an objective need arising from the social evolution of Brazil - which in 1922 was at a time of ruptures - and the development of its working class. In Marx's view, it corresponded to the transformation of the proletariat from "a class in itself" to "a class for itself". The method of analysis used was historical and dialectical materialism. The conclusion that emerges from this study is that the continuity of the Communist Party of Brazil - despite all the persecutions it suffered - expresses the existence of political space for a project of radical and revolutionary transformation of Brazilian capitalist society - one that is different of reformist projects of the bourgeoisie and petty bourgeoisie.

Keywords: Communist Party of Brazil. Marxism. Working class. 


\section{INTRODUCÃ̃O}

Em 25 de março de 2022, o Partido Comunista do Brasil completa um século de existência, caso único entre os diversos partidos operários criados no início do século passado. Que razões levaram ao surgimento do PC do Brasil, o partido mais longevo do país, e fizeram com que ele - sempre perseguido, que nenhum benefício pessoal oferece a seus membros, formado por pessoas simples do povo, carente de recursos financeiros - tenha permanecido vivo e atuante até os dias de hoje?

Para responder a essa pergunta, é preciso ter em conta que a história política e social do nosso país, nos últimos cem anos, não pode ser entendida sem ter em conta o protagonismo da classe operária brasileira. Por sua vez, é impossível analisar esse protagonismo sem conhecer a trajetória do Partido Comunista do Brasil. Como afirmou o poeta Ferreira Gullar, referindo-se a ele: "Quem contar a história do nosso povo e seus heróis tem que falar dele. Ou estará mentindo." (MARÇAL, I986, p. 5)

\section{OS PRIMÓRDIOS DO MOVIMENTO OPERÁRIO BRASILEIRO}

Apesar da tardia industrialização e da persistência da escravidão até I888, as primeiras organizações de trabalhadores - com caráter mutualista (ajuda mútua) surgiram no Brasil já nos anos 30 do século XIX, depois que a Constituição brasileira de I824 acabou com a organização corporativa por ofícios.

Assim, temos notícia da existência, entre outras, da Sociedade Montepio dos Artífices da Bahia (1832), da Sociedade de Oficiais e Empregados da Marinha (I833), da Sociedade de Mecânica Aperfeiçoadora das Artes e Beneficente do Rio de Janeiro (I836), da Sociedade Bem-Estar dos Caixeiros do Rio de Janeiro (I836), da Sociedade de Auxílio Mútuo dos Empregados da Alfândega (I838), da Imperial Associação Tipográfica Fluminense (I853), da Sociedade União Beneficiente dos Cocheiros (I856), da Sociedade Beneficiente do Arsenal de Marinha da Corte do Rio de Janeiro (I858) e da

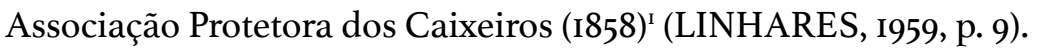

A primeira greve de que temos notícia certa foi a dos tipógrafos cariocas, em I858, reivindicando aumento de salários. Em I863, aconteceu a greve dos trabalhadores da Estrada de Ferro Pedro II, em Barra do Piraí, no Rio de Janeiro, e, em I866, a greve dos caixeiros do Rio de Janeiro, reivindicando o fechamento do comércio à noite e aos domingos.

A partir de meados dos anos 60 do século XIX, multiplicaram-se as publicações de trabalhadores, sendo um dos primeiros o Jornal dos Tipógrafos do Rio de Janeiro, em I858.

Inicialmente, prevaleceram as entidades de caráter assistencialista e recreativo. Apesar de as primeiras organizações de luta já terem surgido nos anos 70 do século XIX, foi somente nos anos 80 que o movimento operário ingressou na etapa de predomínio das entidades de resistência - ligas, sindicatos e uniões operárias —,

1 Não há informação sobre a abrangência territorial de algumas dessas entidades, mas tudo indica ser o Rio de Janeiro. 
inicialmente de orientação social-democrata. Esse segundo período se estendeu até meados da primeira década do século XX, quando o anarcossindicalismo impôs a sua hegemonia. Mesmo assim, as organizações mutualistas mantiveram a sua importância, pelo menos até a segunda década do século XX.

As primeiras tentativas de criar partidos operários e socialistas datam dos anos 90 do século XIX:

A formação partidária que se diz socialista aparece somente depois de I890, isto é, na República [...; seus dirigentes, com exceção, não são de origem proletária, mas pequeno-burguesa, e a maior parte é brasileira, ao contrário das lideranças sindicais [...;] a soma de partidos é espantosa para a época. Temos um Partido Operário do Rio Grande do Sul (189o); Partido Operário ou Partido Socialista Brasileiro, do Distrito Federal (189o); Partido Operário de São Paulo (189o); Partido Operário no Brasil, do Distrito Federal (I892); Centro Operário da Bahia (1894); Partido Operário Socialista, do Distrito Federal (1895); Centro Socialista de São Paulo (1896); Partido Democrático Socialista, de São Paulo (I896); Partido Socialista do Rio Grande do Sul (I897); Partido Socialista Brasileiro, de São Paulo (1902); Partido Operário Socialista, do Distrito Federal (1909) (CARONE, 1996, p. 26).

Acrescenta-se que em I5 de junho de I89o foi criado no Ceará o Partido Operário, que publicava o jornal O Combate. Esses partidos “operários" e "socialistas", apesar de importantes enquanto expressão do amadurecimento político da classe operária brasileira, tiveram vida efêmera e pouca influência sobre as massas.

Em I $^{\circ}$ de agosto de I892, ocorreu no Rio de Janeiro o $\mathrm{I}^{\circ}$ Congresso Socialista, com o objetivo de unificar os diversos partidos operários que existiam no país. Foi decidido criar o Partido Operário Brasileiro, que passou a publicar o jornal O Socialista. O programa aprovado mostra clara influência marxista:

Considerando que a socialização da produção concentra todas as rendas [...] nas mãos da classe capitalista, enquanto a classe operária é submetida a uma exploração física e moral cada vez mais acentuada; considerando que, nas condições econômicas da sociedade atual, a classe operária não poderá jamais se libertar da tutela do capital a não ser que ela se apodere dos meios de produção, isto é, das máquinas, ferramentas, matérias-primas [...] (HARDMAN; LEONARDI, 199I, p. I88-I89).

Em janeiro de I893, Kautsky enviou uma carta a Engels referindo-se àquele partido brasileiro:

envio-te anexo um jornal que me remeteram do Rio de Janeiro. Contém um artigo sobre o Partido Operário Brasileiro e seu programa. Lamentavelmente não sei português e, portanto, só posso adivinhar aqui e ali algo de seu conteúdo. Talvez te interesse o artigo. Talvez, se valesse a pena, Ede [Eduard Bernstein], que também é poliglota, pudesse fazer uma nota com esse material. Já mencionei uma vez o movimento brasileiro, em uma informação baseada em um jornal alemão de São Paulo (MARX; ENGELS, 1982, p. I8I). 


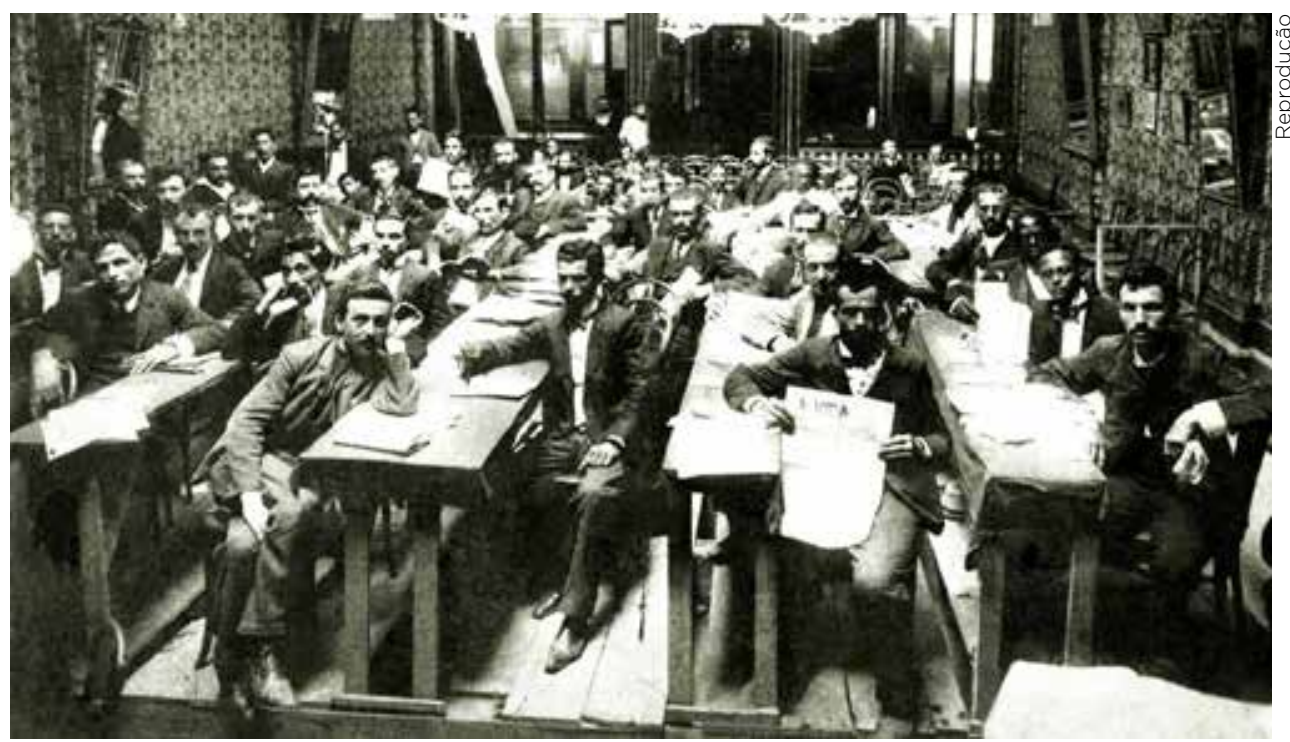

Realizado no Rio de Janeiro em 1906, o $1^{\circ}$ Congresso Operário do Brasil cria a Confederação Operária Brasileira (COB)

Engels respondeu: "Dei a Ede o jornal brasileiro, mas disse-lhe que a importância desses partidos sul-americanos está sempre na razão inversa das demonstrações ruidosas de seus programas." (MARX; ENGELS, I982, p. I4I)

O Partido Operário do Brasil enviou um relatório ao $3^{\circ}$ Congresso da Internacional Socialista (Zurique, agosto de I893), que teve uma de suas sessões presidida por Friedrich Engels.

Os socialistas de São Paulo e do Rio Grande do Sul também mereceram uma referência especial no livro Le socialisme et le Congrès de Londres, editado em I897 na capital inglesa: "No Brasil o socialismo encontra-se em estado embrionário. Cresce mais na Província do Sul, São Paulo e Rio Grande do Sul, graças à imigração italiana e alemã. Em Santos (SP) existe a União Operária, um partido operário, social-democrata." (BANDEIRA, I980, p. 2I)

Apesar da pequena difusão do marxismo no Brasil, já em fins do século XIX encontramos ideias marxistas na imprensa operária e nos documentos dos partidos socialistas de então. O jornal Democracia Social, surgido em I893, em Pelotas, estampava sob o seu título a frase "Trabalhadores de todo o mundo, uni-vos!", seguida do nome de seu autor - "Karl Marx". Referindo-se a ele, o jornal Echo Operário, de Rio Grande, afirmou em I898: "Democracia Social, que, rompendo com os preconceitos estúpidos da sociedade burguesa, arvorou o pendão do socialismo revolucionário científico [....] a emancipação das classes proletárias, a guerra ao capital, a emancipação da mulher." (PETERSEN; LUCAS, 1992, p. 75)

Em 6 de maio de I896, o jornal A Federação publicou em francês a letra de "A Internacional":

Esse texto fora apreendido no porto de Rio Grande, com alguns anarquistas, juntamente com um vasto material "subversivo". É a primeira vez que esse texto é pu- 
blicado no Brasil. Essas publicações em A Federação provocaram uma furiosa reação dos velhos coronéis, que acusaram o jornal de estar sendo dirigido por um bando de jacobinos (MARÇAL, s.d.[b], p. 2).

Em I897, foi criado o Partido Socialista Rio-Grandense, cujo programa defendia o socialismo, a república democrática social, o voto universal (inclusive para mulheres), as mais amplas liberdades, instrução geral e profissional gratuita para os filhos dos pobres, redução dos exércitos, assistência médica gratuita, imposto progressivo sobre heranças e fortunas, jornada de oito horas, proibição do trabalho para menores de I4 anos, jornada de cinco horas para os jovens de I4 a I8 anos etc.

Pela sua proximidade e relação com o movimento socialista do Uruguai e da Argentina,

depois de São Paulo, era no Rio Grande do Sul [...] que a tendência socialista do movimento operário estava mais expandida, havendo núcleos em várias cidades. Em I896, num manifesto publicado no dia $\mathbf{I}^{\mathbf{0}}$ de maio, a Liga Operária Internacional de Porto Alegre chama as demais associações operárias do estado a se organizarem em nível regional. A discussão foi levada durante dois anos. Finalmente, em janeiro de I898, realiza-se o Primeiro Congresso Operário do Rio Grande do Sul (HARDMAN; LEONARDI, I99I, p. 192).

Esse congresso, realizado em Porto Alegre de $\mathrm{I}^{\mathrm{o}}$ a 2 de janeiro de $\mathrm{I} 898$, fundou a Confederação Operária Sul-Rio-Grandense, que adotou o socialismo. Nele, foi vivamente aplaudido telegrama, procedente de Alegrete, que dizia: "Viva o socialismo científico!" (PETERSEN; LUCAS, I992, p. IIo).

Não tendo vingado o Partido Operário Brasileiro, criado em I892, realizou-se em São Paulo, entre 28 e 3 I de maio de I902, o $2^{\circ}$ Congresso Socialista, com a participação de representantes de associações operárias e socialistas de São Paulo, Rio Grande do Sul, Minas Gerais, Pernambuco, Paraná, Pará e Paraíba. Sua debilidade foi a ausência de qualquer representação socialista do Rio de Janeiro, então o principal centro operário do Brasil e onde o socialismo não havia fincado raízes. O Congresso aprovou a fundação do Partido Socialista Brasileiro (PSB), cujo programa tinha clara inspiração marxista:

A classe dos capitalistas, pelo monopólio dos meios de produção e de circulação das riquezas, está em condições de exercer sobre o trabalho alheio um domínio e uma exploração insuportáveis [...; ] as reivindicações dos trabalhadores são idênticas no mundo inteiro [...; consequentemente, a resistência e a luta do proletariado devem ser universais, têm o dever de se incorporar ao grande partido internacional. [...] Mas a emancipação do proletariado e a igualdade de direitos para todos não podem ser obtidos sem que os meios de produção [...] passem da propriedade individual para a propriedade coletiva (HARDMAN; LEONARDI, 199I, p. 195). 


\title{
Em 1906, a Federação Operária Regional do Rio de Janeiro realizou, de 15 a 20 de abril, o 1ํ Congresso Operário do Brasil. Estavam presentes cerca de 40 entidades do Rio de Janeiro, São Paulo, Rio Grande do Sul, Ceará, Pernambuco, Bahia, Alagoas e Minas Gerais. Os anarquistas, apesar de minoritários, dominaram o plenário, aprovando resolução contra qualquer participação política
}

Em 1905, foi criado o Partido Operário Rio-Grandense, cujo "Manifesto ao operariado gaúcho" exigia um lugar ao sol para o proletariado, citava Marx e ameaçava com a "violência dos usurpados":

\begin{abstract}
a inevitável reorganização social já se prenuncia na Europa, onde, para efetuá-la, os proletários, precursores do advento da justiça, vão passando da ação apenas doutrinária à luta armada, obrigados a responder à violência dos usurpadores com a violência dos usurpados. [...] O quarto estado precisa, deve e há de fazer valer os seus direitos, influindo no governo! É mister que ele seja emancipado, porém não esqueçamos que, conforme os ensinamentos do grande mestre Carlos [Karl] Marx, a emancipação do proletariado deve ser obra dele mesmo (PETERSEN; LUCAS, I992, p. I3I).
\end{abstract}

Entre os anos de 1903 e I909, ocorreram inúmeras greves e mobilizações operárias em todo o país, como a dos 25 mil cocheiros e carroceiros do Rio de Janeiro (1903), a dos ferroviários paulistas (1905), a dos portuários de Santos (1905) — em solidariedade à Revolução Russa de 1905 - , a greve geral de 2I dias em Porto Alegre (I906), os atos de repúdio ao fuzilamento de Francisco Ferrer na Espanha (I909) etc.

Em I906, a Federação Operária Regional do Rio de Janeiro realizou, de I5 a 20 de abril, o I $^{\circ}$ Congresso Operário do Brasil. Estavam presentes cerca de 40 entidades do Rio de Janeiro, São Paulo, Rio Grande do Sul, Ceará, Pernambuco, Bahia, Alagoas e Minas Gerais. Os anarquistas, apesar de minoritários, dominaram o plenário, aprovando resolução contra qualquer participação política. O congresso ainda aprovou a luta pela jornada de oito horas, a denúncia da guerra e do militarismo, a comemoração pública do Primeiro de Maio e a criação da Confederação Operária Brasileira (COB), efetivada dois anos depois. Segundo Astrojildo Pereira: 
no Congresso Operário de 1906 manifestou-se uma forte corrente favorável à formação de um partido político operário; mas a corrente anarcossindicalista predominou ali de maneira irredutível, com o seu visceral preconceito "antipolítico". Nasceu, assim, em vez de um partido, a COB [...;] o espírito de revolta reinante nas massas de trabalhadores [...] viria a favorecer entre nós o surto do anarquismo, uma vez que o socialismo [...] se apresentava aqui quase sempre sob as vestes do mais frouxo reformismo, que apenas de nome ouvira falar de Marx e do marxismo [...; ] o anarquismo, sobretudo em sua forma anarcossindicalista, predominou no movimento operário brasileiro durante os anos que vão de 1906 a I920 (PEREIRA, I976, p. 34-35).

De 7 a I5 de novembro de I9I2, realizou-se no Rio de Janeiro, no luxuoso palácio Monroe, um autodenominado $4^{\circ}$ Congresso Operário Brasileiro, organizado e financiado pelo primeiro-tenente e deputado federal Mário Hermes - filho do então presidente da República, marechal Hermes da Fonseca. O assim chamado "congresso dos pelegos" entregou a presidência de honra da recém-fundada Confederação Brasileira do Trabalho ao deputado Mário Hermes, pouco mais se sabendo dela desde então.

Entre 8 e 13 de setembro de 1913 , a COB realizou o $2^{\circ}$ Congresso Operário Brasileiro, no Rio de Janeiro. Estiveram representados os estados de São Paulo, Rio de Janeiro, Rio Grande do Sul, Distrito Federal, Minas Gerais, Pará, Alagoas e Amazonas. $\mathrm{O} 2^{\circ}$ Congresso indicou greve geral revolucionária em caso de guerra externa, condenou o cooperativismo nas entidades sindicais (por "desvirtuar os destinos reais do sindicato") e assumiu integralmente a orientação anarquista de repúdio à política.

De I9I2 a I9I6, houve um refluxo das lutas operárias, só retomadas no ascenso de I9I7-I9I9:

\begin{abstract}
Nos anos de I9II até I913 passa-se por um certo refluxo, quando os desmantelamentos de sindicatos pela polícia serão acompanhados de legislação mais severa para expulsão de estrangeiros. Daí até 1917 uma relativa baixa do movimento grevista é acompanhada de forte mobilização contra a expulsão de estrangeiros, contra a guerra e o militarismo, contra a carestia que acompanhou os anos de guerra. O ano de 1917 inaugura um novo ascenso e mesmo uma nova fase de massividade do movimento operário (LÖWY, I980, p. I8).
\end{abstract}

Apesar disso, em 2 de agosto de I9I4, logo após o início da Primeira Guerra Mundial, o operariado de São Paulo fez um ato de protesto contra a guerra, na praça da Sé, apesar da proibição policial. O mesmo foi feito em Santos, onde a sede da Federação Operária foi fechada e diversos dirigentes sindicais foram presos.

No Primeiro de Maio de I915, ocorreram atos contra a guerra no Rio de Janeiro e São Paulo. Entre I4 e I6 de outubro, a Confederação Operária Brasileira realizou no Rio de Janeiro o Congresso da Paz, com delegações de São Paulo, Pernambuco, Alago- 
as, Rio de Janeiro, Minas Gerais e Rio Grande do Sul e representações da Argentina, Portugal e Espanha.

\title{
3. O ASCENSO DAS LUTAS OPERÁRIAS EM 1917
}

Para compreendermos a grande onda grevista de I9I7, é preciso analisar além de suas causas de fundo - a conjuntura em que ela ocorreu. Miguel Bodea, no seu livro sobre a greve geral de i9I7, diz que

\begin{abstract}
o grande movimento grevista que se alastrou pelo país em meados de 1917 tem a sua causa conjuntural mais evidente no modo de inserção do Brasil na Primeira Grande Guerra [...; o país transformara-se em um grande fornecedor de gêneros alimentícios às populações civis e às tropas combatentes das nações da "Entente" (BODEA, s.d., p. 2I).
\end{abstract}

Os dados do comércio exterior do Brasil (Diretoria de Estatística Comercial, Rio de Janeiro) nos indicam que entre I9I4 e I9I7 as exportações brasileiras de gêneros alimentícios aumentaram enormemente. No caso da carne resfriada e do charque, esses aumentos foram de 47 e de 30 vezes, respectivamente. Já a exportação de milho aumentou quase 8 mil vezes, a de arroz, mais de I4 mil vezes, e a do feijão, 2I mil vezes! As consequências foram o desabastecimento da população e a disparada dos preços. Entre I9I4 e I9I7 os preços praticamente duplicaram (82\%), e entre I9I4 e I9I9 quase triplicaram (I85\%) (BODEA, s.d., p. 2I-22). Esse enorme aumento dos preços ocorreu com salários nominais fixos, o que significou uma piora considerável das condições de vida dos trabalhadores.

Referindo-se a essa mesma conjuntura, Dulles reforça:

Os preços dos gêneros alimentícios continuaram a subir durante os seis primeiros meses de 19I7. Artigos de primeira necessidade tendiam a custar de $20 \%$ a $150 \%$ mais caro do que no ano precedente [...]. O aumento do custo de vida foi o tema dos discursos do Primeiro de Maio de 1917 (DULLES, I977, p. 47).

A essa difícil situação econômica somou-se o impacto da Revolução Russa de fevereiro de I9I7 e o razoável nível de consciência e organização que os trabalhadores já haviam alcançado.

De outra parte, para compreendermos a greve de I9I7, é necessário fazer uma rápida análise do desenvolvimento industrial brasileiro nesse início do século XX.

Segundo o censo industrial de 1907, o Distrito Federal contava com 34.850 operários (23,4\% do total do país), o estado de São Paulo, com 24.I86 operários (I6,2\%), e o Rio Grande do Sul, com 15.426 operários (IO,4\%). Ou seja, essas três unidades da Federação tinham 50\% do proletariado industrial brasileiro. Após, vinham o Rio de Janeiro, com 13.632 operários (9,I5\%), e Pernambuco, com 12.042 operários (8,1\%) (CARONE, I996, p. 19). Não estavam incluídos nesses dados os trabalhadores nos serviços públicos, transporte, comércio, bancos, serviços em geral. O Rio de Janeiro respondia 


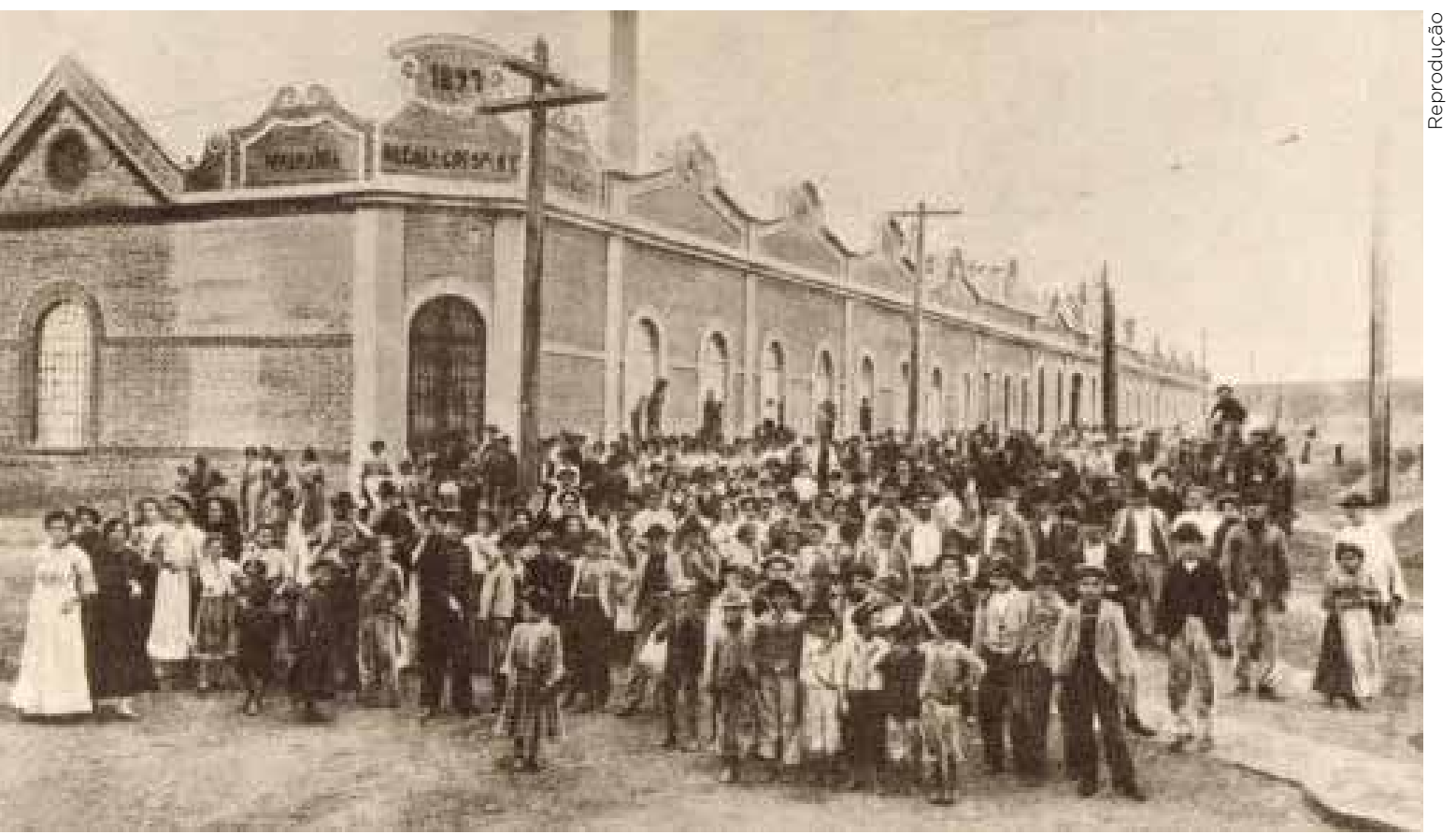

À época do predomínio anarcossindicalista, houve no país intensa agitação operária. Memoráveis greves gerais foram realizadas. Um dos movimentos mais importantes foi a Greve Geral de São Paulo, ocorrida em 1917. Na foto acima, têxteis do Cotonifício Crespi na Mooca, iniciadores da greve geral

por $33 \%$ da produção manufatureira do país, São Paulo, por I6\%, e o Rio Grande do Sul, por $15 \%$, totalizando $64 \%$ do total nacional.

Quanto à sua nacionalidade, a classe operária era bastante heterogênea. Pelo censo de 1920, na cidade de São Paulo, 54,3\% dos trabalhadores industriais, de transportes e do comércio eram estrangeiros. Já em Porto Alegre, eles eram apenas 25,3\% (BODEA, s.d., p. 24-27). Essa diferença decorria do fato de as imigrações alemã e italiana, no Rio Grande do Sul, datarem de I824 e I875, respectivamente, e terem ocorrido nas áreas rurais, fazendo com que a maioria dos operários não fossem imigrantes, e sim filhos ou netos de imigrantes.

Pelas razões acima expostas, o ano de 1917 iniciou prenhe de grandes mobilizações operárias.

Em I8 de abril, a Federação Operária do Rio de Janeiro - após uma maciça assembleia - enviou uma mensagem ao presidente da República contra a eventual entrada do Brasil na guerra e exigindo medidas para enfrentar a crise que esmagava os trabalhadores. No Primeiro de Maio, uma grande massa de trabalhadores desfilou pelas ruas da capital, protestando contra a carestia e clamando por "paz". Ainda em maio, irromperam greves nas fábricas têxteis do Rio de Janeiro, acompanhadas de comícios, passeatas e choques com a polícia. Em julho de I9I7, eclodiu em São Paulo - já então o principal centro industrial do Brasil - a primeira greve geral do país, que logo se estendeu para o Rio de Janeiro, Rio Grande do Sul e Pernambuco. 


\section{A GREVE GERAL DE 1917 EM SÃo PAULO}

Em Io de junho, teve início a greve dos trabalhadores do Cotonifício Crespi, no bairro da Mooca, na capital paulista, reivindicando aumento de $25 \%$. No dia 15 , uma passeata dos grevistas sofreu forte repressão policial. Logo o movimento ganhou a adesão dos operários de diversas fábricas, e o descontentamento se generalizou entre os trabalhadores.

No dia 28 de junho, a União dos Operários em Fábricas de Tecidos de São Paulo apelou às ligas operárias do interior de São Paulo, Rio de Janeiro, Rio Grande do Sul e Minas Gerais para que declarassem boicote, impedindo que o Cotonifício Crespi atendesse a suas encomendas através de fábricas fora de São Paulo. Nesse dia, outra grande manifestação foi reprimida pela polícia quando se dirigia à praça da Sé.

Em 6 de julho, a empresa Nami Jafet concedeu um aumento de $20 \%$ aos trabalhadores do dia e de $25 \%$ aos da noite. O movimento se disseminou, e logo passaram a ser milhares de grevistas nas ruas. No dia 9 de julho a polícia fechou as sedes de todas as ligas e uniões da cidade e disparou contra os trabalhadores, ferindo gravemente o operário Antonio Martínez. A greve se espalhou por Sorocaba, Campinas, Jundiaí, Santos, Ribeirão Preto, Rio Claro e São Carlos, entre quase todas as categorias industriais. Cresceram os choques com as forças da repressão e a indignação proletária.

No dia ı, o operário Martínez faleceu e a Comissão de Defesa Proletária convocou a população de São Paulo a acompanhar o enterro. Um "mar de gente" acompanhou o cortejo fúnebre, desafiando o aparato policial-militar posto na rua pelo governo. Findo o enterro, uma parte da massa dirigiu-se à praça da Sé, para um ato de protesto. Outra parte da multidão - calculada em milhares de pessoas - dirigiu-se para os bairros do Brás, Mooca, Pari, Barra Funda, Lapa e Cambuci, armou barricadas e forçou o fechamento das empresas que estavam trabalhando. Multidões saquearam armazéns e o comércio cerrou as portas.

Os dias 12 e 13 de julho foram de confrontos abertos, vários armados, entre os trabalhadores e as forças da repressão. Subia a dezenas de milhares o número de trabalhadores em greve. Manifestações de solidariedade chegavam de todas as partes. Sucediam-se os atos de indisciplina no seio das tropas, causando preocupação às autoridades e aos patrões:

$\mathrm{O} \mathrm{I}^{\mathrm{o}}$ e o $4^{\mathrm{o}}$ batalhões da Força Pública tornaram-se suspeitos, pois se deram diversos casos de "insubordinação", isto é, recusa de praticar violências contra os grevistas [...;] há deserções na força pública e outros soldados alegam doença para não intervir na repressão contra o povo trabalhador (DIAS, I962, p. 298-299).

No dia 13 de julho, Crespi e os demais industriais concederam um aumento de $20 \%$ ao conjunto dos trabalhadores. Após algumas negociações, além do aumento de $20 \%$, os patrões se comprometeram a não despedir ninguém pela greve, respeitar 
o direito de associação, pagar os salários a cada 15 dias e melhorar as condições materiais e econômicas dos trabalhadores. O governo libertou os detidos devido à greve, reconheceu o direito de reunião e comprometeu-se a exercer uma fiscalização rígida das normas trabalhistas e um controle dos preços. No dia I6 de julho, os grevistas aceitaram o acordo.

No dia I8 de julho, "ao comício do largo da Concórdia aflui uma massa superior a 80 mil almas. Um verdadeiro oceano humano a espraiar-se pelo largo até a rua Bresser. Nunca se viu, na cidade, uma concentração tão numerosa, tão comovente e tão conscientemente disciplinada" (DIAS, I962, p. 303). O comício foi encerrado ao som de "A Internacional".

\section{A GREVE GERAL SE ALASTRA PARA O RIO DE JANEIRO}

Ainda em I8 de julho de I9I7, o movimento grevista eclodiu no Rio de Janeiro. Iniciado em duas pequenas fábricas de móveis, em solidariedade aos grevistas de São Paulo, se estendeu rapidamente, sob a liderança da Federação Operária do Rio de Janeiro:

Na manhã de segunda-feira, 23 de julho, calculava-se que 50 mil operários estavam em greve. No mesmo dia, cerca de 20 mil operários metalúrgicos deixaram o serviço. À noite, os alfaiates e os entregadores de pão decidiram aderir ao movimento. No dia 24, os sapateiros fundaram a União dos Cortadores de Calçado e exigiram a jornada de oito horas, bem como aumento salarial de $20 \%$. Os grevistas da companhia de tecido América Fabril exigiram aumento de 30\% e escolas para as crianças. Os operários de outra companhia têxtil, a Fábrica de Tecidos Aliança, pediram aumento de $30 \%$ e o término dos castigos corporais. Bandos de operários percorreram as ruas da cidade. A 24 de julho, enquanto um grupo deles solicitava a adesão de companheiros ao movimento paredista, a polícia investiu contra o mesmo a golpe de espada e patas de cavalo. A multidão, revoltada com esse "ataque" policial, marchou em direção ao largo de São Francisco, carregando uma bandeira vermelha e berrando "Abaixo o capital". [...] Enquanto isso, outros grupos executavam os primeiros assaltos e depredações. [...] Em 25 de julho, uma força policial dispersou enorme aglomeração nas vizinhanças da Central de Polícia [...; os policiais foram recebidos a pedra, saindo ferido na cabeça o tenente que comandava o destacamento [...;] a 26 de julho [...] os operários e patrões das fábricas de calçados chegaram a um acordo com a fixação do salário mínimo de 8 \$50o [8.500 reis] [...; ] os sapateiros retornaram ao trabalho. O movimento grevista, no entanto, ganhou a adesão dos operários de várias fábricas, fortalecida pela do pessoal da limpeza pública. Nos últimos dias de julho, diversos acordos foram efetuados. Os representantes dos operários das fábricas de tecidos, maior dos grupos trabalhistas do Rio, ainda se encontravam em negociações no dia $\mathrm{I}^{\circ}$ de agosto. Quando, no dia seguinte, entraram em acordo com o Centro Industrial do Brasil, a "greve geral" carioca chegou ao ponto final. O acordo estabelecia a semana máxima 


\section{Os confrontos entre operários e policiais prosseguiram no Rio de Janeiro em setembro e outubro, levando as lideranças sindicais - majoritariamente anarquistas - a propor uma greve geral insurrecional, com o objetivo de derrubar o Estado burguês e substituí-lo por conselhos de trabalhadores. Entre os principais organizadores do movimento estavam Astrojildo Pereira, José Elias da Silva e João da Costa Pimenta, que em 1922 viriam a fundar o Partido Comunista do Brasil}

de 56 horas e um aumento de I0\% dos vencimentos. Os problemas referentes ao dia de oito horas, trabalho de menores e responsabilidade dos patrões nos acidentes de trabalho seriam resolvidos por leis no Congresso Nacional. E nenhum operário seria dispensado por tomar parte na greve (DULLES, I977, p. 58-59).

\section{A GREVE GERAL CHEGA AO RIO GRANDE DO SUL}

Diante das greves gerais do Rio de Janeiro e de São Paulo, desde 2I de julho a imprensa porto-alegrense cogitava da iminência da eclosão de uma greve no estado. A Federação Operária do Rio Grande do Sul (Forgs), que naquele momento não era dirigida pelos anarquistas, trabalhou para que a greve não acontecesse:

greve era um caminho que se colocava quase naturalmente por todo o contexto local e nacional, mas não era essa a posição da federação [...; não é surpreendente, portanto, a [...] declaração da Forgs ao Correio do Povo de que "não cogita de greve, tendo até mesmo se esforçado junto às associações que lhe são federadas para que esta capital nada venha a sofrer na sua tranquilidade" (PETERSEN, 200I, p. 328-329). 
A União Operária Internacional, anarquista, convocou então uma reunião, na Forgs, no dia 29:

Na reunião, com mais de 500 pessoas, nenhum cargo administrativo da Forgs tomou a palavra, e criou-se [...] um órgão sob controle dos anarquistas e dos pedreiros sindicalistas (sem a participação da diretoria da federação). A Liga de Defesa Popular (LDP) estabelece uma pauta de reivindicações e a entrega aos governos municipal e estadual, eximindo, portanto, a Forgs da responsabilidade do movimento (SILVA JR., 1996, p. 188).

\section{Em seguida, a liga lançou uma proclamação ao povo de Porto Alegre:}

Povo! Trabalhadores! [...] A Liga de Defesa Popular espera o apoio do povo de Porto Alegre para obter as seguintes melhorias [...]:

- Diminuição dos preços dos gêneros de primeira necessidade em geral.

- Providência para evitar o açambarcamento do açúcar.

- Estabelecimento de um matadouro municipal para fornecer carne à população a preço razoável.

- Criação de mercados livres nos bairros operários.

- Obrigatoriedade de venda do pão a peso e fixação semanal do preço do quilo.

- A Intendência cobrar pelo fornecimento de água IO\% sobre os aluguéis cujo valor locativo seja inferior a $40 \$ 000$ [40 mil réis].

- Compelir a Companhia de Força e Luz a estabelecer a passagem de Ioo réis, de acordo com o contrato feito com a municipalidade.

- Aumento de $25 \%$ sobre os salários atuais.

- Generalização da jornada de oito horas.

- Estabelecimento da jornada de seis horas para mulheres e crianças (PETERSEN, I979, p. 308-309).

Em 30 de julho, a liga enviou um documento ao presidente do estado - Borges de Medeiros - e ao intendente municipal - José Montaury - com as reivindicações aprovadas. No dia 3I, em um comício com mais de 5 mil pessoas, foi decretada a greve geral:

Estalou finalmente a greve geral, há tantos dias anunciada nesta cidade, e cujos prenúncios se fizeram sentir logo após o movimento grevista que na capital da República secundou o de São Paulo. Como era de prever, o operariado, depois do comício realizado ontem à tarde na praça Senador Florêncio, onde diversos oradores pregaram a greve geral como único meio de conseguir o decrescimento da carestia da vida, resolveu abandonar o trabalho, tendo muitas fábricas deixado de funcionar ontem mesmo. A agitação nas classes operárias é extraordinária, como se pode notar, desde ontem à tarde, na atitude exaltada de grande número de operários que, em grupos, percorriam as ruas da cidade e estacionavam às esquinas (PETERSEN; LUCAS, 1992, p. 203-204). 
Paralisaram suas atividades os calceteiros, pedreiros, marceneiros, carpinteiros, tecelões, chapeleiros, metalúrgicos, estivadores, choferes, carroceiros, padeiros, tipógrafos, comerciários e trabalhadores em bondes. Os grevistas passaram a ter como porta-voz o jornal A Época, editado por Zenon de Almeida, que anos depois seria um dos organizadores do Partido Comunista do Brasil:

Zenon de Almeida teve papel destacado na série de greves de 1917, integrando seu grupo dirigente. "Foram greves violentas, com depredações, incêndios e atentados à bomba”, lembra seu filho. [...] Zenon foi um dos editores de $A$ Época, porta-voz da Liga de Defesa Popular, entidade que assume o comando da capital, enquanto governo, brigada e polícia enfiam o rabo entre as pernas nos seus respectivos redutos [...; com Geyer e Djalma, aperfeiçoou um detonador que transformasse a dinamite em granadas de mão [...; conseguiram um petardo que, em 1917, apavorou a brigada, tirando-lhe a iniciativa (MARÇAL, 1995, p. 38).

\section{Uma testemunha da época reproduz bem o clima da greve:}

Invadindo e dominando todas as grandes companhias, estabelecimentos e várias classes sociais, algumas levadas à força, pelo temor de represálias tremendas que os grevistas prometiam [..., esse movimento assumiu proporções desmesuradas, paralisou totalmente a vida da cidade, sem luz nem pão, sem leite nem carne, sem legumes nem frutas, sem bondes nem carros, sem automóveis nem carroças [...; grevistas que chegaram à petulância irrisória de colocar destacamentos seus, vigilantes e ameaçadores, em determinadas embocaduras e encruzilhadas, para impedir que os vendedores ambulantes dos artigos imprescindíveis de consumo diário pudessem chegar ao mercado ou casas dos fregueses. Houve até um simulacro caricato de governo que expedia salvo-condutos a determinados indivíduos para poderem transitar livremente. Dispondo de numerosa gente espalhada aqui e acolá em grupos de catadura menos tranquilizadora, foram a reprováveis atos de violência [...]. A cidade semelhava uma praça de guerra, preparada para o combate. Em todos os recantos suspeitos, os pelotões de infantaria, embalados, estacionavam previdentes: patrulhas de cavalaria cruzavam constantemente numa atividade formidável. [...] Os comícios e assembleias operárias eram frequentes e numerosas, a linguagem tribunícia, inflamada, excessiva, abundantíssima; as exigências, enormes; as imposições, demasiadas e inaceitáveis; a cólera, exacerbada e perigosa (PETERSEN; LUCAS, 1992, p. 204-205).

No dia 2 de agosto, Borges de Medeiros reduziu a jornada e concedeu aumentos salariais de $5 \%$ a $25 \%$ aos trabalhadores do estado, além de tomar medidas de controle das exportações de arroz, banha, batatas, feijão e farinha. Mas, como o governo municipal não tomou medidas para controlar os preços nem os patrões reduziram a jornada de trabalho ou deram aumento salarial, a greve prosseguiu.

No dia seguinte, o intendente municipal tabelou os preços do arroz, açúcar, 
banha, cebola, salame, ovos, erva-mate, leite, manteiga, massa branca, milho, fósforos, polvilhos, pão, sal, charque, querosene, sabão e vela de sebo e editou normas para a venda da carne. Os patrões, pressionados pelos trabalhadores e pelo governo, aceitaram a jornada de oito horas e deram aumentos de $25 \%$ para a maioria das categorias.

Um grande comício, no dia 5 de agosto, encerrou a "guerra dos braços cruzados", mas algumas categorias permaneceram em greve, até terem as suas reivindicações atendidas.

Já os ferroviários, enfrentaram enormes dificuldades. Dia 3I de julho, a greve eclodiu em Porto Alegre, Santa Maria, Pelotas, Rio Grande, Bagé, Gravataí, Passo Fundo, Cacequi, Rio Pardo e Couto. A concessionária belga da Viação Férrea do Rio Grande do Sul (VFRGS) negou-se a atender às demandas dos grevistas — jornada de oito horas, semana inglesa, aumentos salariais de IO\% a 30\% - e pediu a intervenção das tropas da $7^{\text {a }}$ Região Militar:

No dia 2 de agosto o general Carlos Frederico de Mesquita comanda a ocupação da estação de Santa Maria. Em represália os grevistas arrancam trilhos, derrubam pontes e bloqueiam a via com dormentes e postes telegráficos em vários pontos do estado. Alguns trens passam a circular guarnecidos por tropas. Em Passo Fundo há violentos choques entre ferroviários e forças militares (BODEA, s.d., p. 34).

No dia 9 de agosto a greve foi suspensa sem que as reivindicações dos trabalhadores fossem atendidas. Mas em I7 de outubro de I9I7 os ferroviários retomaram a luta, através de uma greve ainda mais violenta e prolongada. Operários armados invadiram a estação de Santa Maria, danificaram locomotivas e as fizeram se chocar, paralisando completamente o tráfego. A greve se espalhou por todo o estado, com uma violência inaudita. Trilhos eram arrancados, linhas telegráficas, cortadas, pontes, destruídas. Novamente as tropas foram mobilizadas, e trens guarnecidos por militares voltaram a circular:

Os insurretos apedrejaram estações, quebraram vidros, dinamitaram pontes, arrancaram trilhos, atacaram trens a tiros de revólveres, tentaram demolir importantes obras de arte, entraram em sérios conflitos, desrespeitaram a força armada, autoridades e os funcionários seus dirigentes. Não houve embaraços que não opusessem para impedir o tráfego oficial, com maquinistas e guarnição do Exército e Brigada Militar, que diligenciavam para não serem de todo interrompidas as viagens dos trens, permitindo assim o transporte de forças que deviam acudir apressadas aos pontos de maior agitação, no intuito de obstar às depredações constantemente praticadas pelos tresloucados grevistas (PETERSEN; LUCAS, I992, p. 206).

Em Santa Maria cresceu a violência: "Em choques de rua, após comício na praça Saldanha Marinho, no dia 2I de outubro, uma patrulha do Exército atira sobre os manifestantes: há um morto e 29 feridos" (BODEA, s.d., p. 60). A Forgs ameaçou, então, com uma greve geral no estado, caso as reivindicações dos ferroviários não fos- 
sem atendidas. No dia 3I, Borges de Medeiros forçou a empresa a conceder aumentos de I0\% a I $5 \%$ e a acatar boa parte das reivindicações dos grevistas. Três anos depois, em I920, a empresa foi estatizada.

Além da paralisação estadual dos ferroviários, a greve geral se alastrou para outras cidades do interior, como Pelotas, onde foi deflagrada no dia 4 de agosto, obtendo ampla adesão. No dia Io de agosto, uma passeata dos trabalhadores foi violentamente reprimida, com diversos feridos. À noite, na sede da Liga Operária, a polícia atacou novamente e os operários resistiram. Na refrega, um funcionário da Intendência Municipal foi gravemente ferido, vindo a falecer poucos dias depois, e o cavalo do próprio chefe de polícia foi morto a tiros. Após muita luta os grevistas foram desalojados. A greve prosseguiu e só foi encerrada em meados de agosto, com a promessa de redução no preço dos gêneros de primeira necessidade.

\section{A GREVE GERAL DE 1917 EM PERNAMBUCO}

Em Pernambuco, a onda grevista chegou em setembro. No dia 4, os trabalhadores da construção civil do Recife - liderados pelo Sindicato dos Ofícios Vários - declararam-se em greve, reivindicando aumento de 50\% nos salários, jornada de oito horas e garantia de $70 \%$ do valor da diária para os acidentados. Paralisaram suas funções pedreiros, marceneiros, carpinas, carpinteiros, pintores e serventes. Logo se somaram a eles cigarreiros, carvoeiros, estivadores, barraqueiros, trabalhadores em estaleiros, condutores de bondes etc.

A repressão do governo e dos patrões não se fez esperar: o presidente do Sindicato dos Ofícios Vários, José Minhocal, foi preso e mantido incomunicável, e o presidente da omissa Confederação Operária de Pernambuco, João Câncio, foi usado para desarticular o movimento. A sede do sindicato foi interditada, e os grevistas, atacados pela polícia e por tropas do Exército. Mesmo assim, a greve se expandiu para outras cidades, entre elas Jaboatão e Morena. Algumas categorias - como os carvoeiros e os estivadores - conseguiram acordos parciais, mas em I5 de setembro a greve foi encerrada (MOREIRA, 2005, p. 45-70).

\section{A INSURREICÃO ANARQUISTA DE 1918}

O ano de I9I8 iniciou-se com a divulgação de notícias sobre a Revolução Russa, o que despertou grande entusiasmo entre os trabalhadores. Em março foi fundada a União Geral dos Trabalhadores, que substituiu a Federação Operária do Rio de Janeiro, interditada em agosto de I9I7.

No Primeiro de Maio, foi decretado o estado de sítio no Rio de Janeiro e os trabalhadores tiveram de comemorar a sua data em recintos fechados. Em uma reunião com 3 mil trabalhadores, foi aprovada uma moção em que o proletariado carioca manifestava a "sua profunda simpatia pelo povo russo, nesse momento em luta aberta 
e heroica contra o capitalismo" (PEREIRA, 1976, p. 48). Ainda em maio, foi deflagrada uma greve dos trabalhadores da fábrica de tecidos Corcovado, duramente reprimida.

Em agosto de I9I8, eclodiu a greve da Companhia Cantareira e Viação Fluminense - que operava os bondes e as barcas do transporte entre o Rio e Niterói - , à qual aderiram diversas categorias. Parte da tropa enviada para reprimir o movimento apoiou os grevistas e ocorreram violentos choques armados:

Bandos enormes de populares [...] bateram-se com a polícia e forçaram os estabelecimentos comerciais a cerrar as portas, aos gritos de "Fecha, fecha!". Na noite de 6 de agosto, por duas vezes a cavalaria da polícia dispersou a golpes de sabre a multidão. Depois de vários soldados do $58^{\circ}$ Batalhão de Caçadores do Exército [...] passarem para o lado da multidão [...,] uma grande massa humana, polvilhada de soldados do $58^{\circ}$ Batalhão, lançou gritos de "Morra!" à polícia e aos "poderes constituídos", de "vivas" ao "anarquismo" e ao "internacionalismo". A carga de espada da cavalaria policial resultou em tiroteio entre a polícia e a multidão. Esgotada a munição, a cavalaria se retirou e tomou-lhe o lugar um contingente de infantaria da polícia estadual, que trocou tiros com soldados do Exército. Cerca de I2 policiais e um número desconhecido de soldados e populares saíram feridos. Duas pessoas morreram no local: Nestor Pereira da Silva, soldado do $58^{\circ}$ Batalhão, e José Oliveira do Amaral, civil. [...] Durante o enorme cortejo fúnebre [..., as autoridades não deixaram nenhum operário falar.

[...] Recebeu-se, no enterro, a notícia do falecimento de Antonio Lara França, um cabo do $58^{\circ}$ Batalhão que fora gravemente ferido na luta de 7 de agosto (DULLES, 1977 , p. 65-66).

Os confrontos entre operários e policiais prosseguiram no Rio de Janeiro em setembro e outubro, levando as lideranças sindicais - majoritariamente anarquistas - a propor uma greve geral insurrecional, com o objetivo de derrubar o Estado burguês e substituí-lo por conselhos de trabalhadores. Entre os principais organizadores do movimento estavam Astrojildo Pereira, José Elias da Silva e João da Costa Pimenta, que em I922 viriam a fundar o Partido Comunista do Brasil. Foi marcada a data de i8 de novembro para a insurreição.

Nessa data, os operários da indústria têxtil iniciaram uma greve no Rio de Janeiro, Niterói, Magé, Petrópolis e Santo Aleixo, que teve a adesão dos trabalhadores da construção civil e metalúrgicos:

Os primeiros a entrar na luta foram 25 mil tecelões, que exigiam aumento de salário e o direito de criar livremente sindicatos. Segundo o plano elaborado por um comitê revolucionário especialmente criado, a greve deveria transformar-se em rebelião armada. Os sindicalistas revolucionários e os anarquistas, que participavam desse comitê, decidiram que o sinal para a rebelião seria uma reunião geral dos proletários, em uma das praças da capital. Depois deveriam invadir depósitos militares e apreender armas [...; em seu meio infiltrou-se um provocador, que comunicou à polícia a rebelião em preparação. Na véspera da rebelião, na noite de 17 para I8 de 
Foi nesse contexto de impotência e de fracasso do anarquismo na condução da luta contra a exploração capitalista que eclodiu a Revolução Russa, dirigida pelo Partido Bolchevique, a qual conduziu o proletariado ao poder, em aliança com o campesinato. A influência desse acontecimento sobre a vanguarda operária brasileira foi enorme. Os "dogmas" anarquistas contra o "partido em si" e contra o "Estado em si" - sem ter em conta o seu caráter de classe caíram por terra!

novembro de 1918, a polícia prendeu vários membros do comitê revolucionário. Os grupos de operários que se reuniram pela manhã em uma das praças foram dissolvidos pela polícia. A rebelião armada fracassou [...; em alguns bairros os operários começaram, de acordo com o plano, a construir barricada, mas logo foram obrigados a recuar. Somente nos arredores do Rio de Janeiro, os trabalhadores de Magé, rebelando-se, proclamaram a República Operária, que durou alguns dias. Os revolucionários tentaram mesmo tomar sob seu controle as fábricas, porém destacamentos policiais afogaram em sangue a República Operária - a primeira tentativa dos operários de tomarem o poder em suas mãos. [...] Muitos operários foram mortos e presos [...;] os acontecimentos de novembro de 1918 demonstraram com toda a evidência que se havia acumulado, nas fileiras do movimento operário, uma grande energia revolucionária, e que espontaneamente os operários eram atraídos a métodos mais revolucionários de ação e que o antagonismo entre o capital e o trabalho havia crescido de maneira excepcional. A questão estava apenas em organizar e dirigir corretamente essa luta. Os sindicalistas mostraram sua incapacidade para continuar desempenhando o papel dirigente. $O$ proletariado brasileiro viu-se diante da necessidade de elaborar uma nova orientação e criar um partido político de tipo bolchevique (KOVAL, I982, p. I49-I5I).

A insurreição anarquista fracassou e foi duramente reprimida. No dia 20, fo- 
ram fechadas as sedes dos sindicatos dos têxteis, dos trabalhadores da construção civil e dos metalúrgicos. A UGT foi dissolvida por decreto federal. Mesmo assim, a greve se manteve por duas semanas, antes de ser derrotada.

\section{AS GRANDES GREVES DE 1919}

Em I3 de março de 1919, em Santana do Livramento, no Rio Grande do Sul, eclodiu uma greve - dirigida pela Liga Comunista de Livramento - nos frigoríficos Armour, exigindo aumento salarial, jornada de oito horas, pagamento em dobro das horas extras e aos domingos. Os patrões se mantiveram intransigentes e o movimento se alastrou para os frigoríficos Wilson, com diversas manifestações de rua. A população — inclusive da vizinha cidade uruguaia de Rivera - passou a apoiar os grevistas. Ao lado, na cidade de Rosário do Sul, a polícia multiplicou as prisões, para que a greve não atingisse os frigoríficos Swift. No Primeiro de Maio, realizou-se uma grande manifestação de rua: "Nessa mesma data, a direção dos frigoríficos Armour e Wilson publicou um boletim reduzindo de dez para nove horas o trabalho diário e aumentando em IO\% o salário dos trabalhadores por hora. O movimento estava vitorioso." (MARÇAL, s.d.[a], p. 2-4).

No Rio de Janeiro, foi realizado um grande ato de Primeiro de Maio, com mais de 60 mil trabalhadores, e vários oradores falaram em nome do "Partido Comunista". O mais aplaudido foi o operário José Elias da Silva, que três anos depois participaria da fundação do Partido Comunista do Brasil.

No dia 2 de maio, o Sindicato dos Trabalhadores da Construção Civil do Rio de Janeiro "decretou" a jornada de oito horas, que acabou se impondo aos patrões. No dia 7 de maio, diversas categorias entraram em greve, e no dia I8, mais de Io mil trabalhadores estavam paralisados, obtendo diversas conquistas.

Também em 2 de maio, teve início em São Paulo uma greve geral que em poucos dias paralisou mais de 50 mil trabalhadores, abrangendo operários de fábricas têxteis de São Paulo, São Caetano e São Bernardo e trabalhadores em padarias, artes gráficas, ateliês de costura, fundições, serrarias, frigoríficos e outros:

\footnotetext{
O movimento se estendeu a outras cidades do estado, de maneira bem mais significativa do que acontecera em 1917. [...] Em São Bernardo do Campo, ao sul da capital, o operário Constante Castellani foi morto por uma bala do destacamento policial que fizera fogo para dispersar uma aglomeração de grevistas (DULLES, 1977, p. 73-74).
}

O movimento grevista obteve vitórias parciais, como redução da jornada de trabalho e aumento salarial.

Nos meses seguintes, eclodiram greves em Rio Grande, Porto Alegre, Recife, Salvador, Niterói e Curitiba. Examinaremos alguns desses movimentos grevistas.

Em 5 de maio, eclodiu no porto de Rio Grande uma greve geral, que envolveu trabalhadores do frigorífico Swift, das obras do Porto Novo, estivadores, motorneiros, 
trabalhadores em serviços de esgoto, operários das fábricas Leal Santos, da cervejaria Schmidt, da Poock, da Ítalo-Brasileira, da União Fabril, de oficinas mecânicas, da viação férrea, marinheiros etc. As principais reivindicações eram a jornada de oito horas, horas extras com $50 \%$ de acréscimo, aumentos salariais e fiscais nomeados pela estiva.

Em Porto Alegre, no mês de julho,

desfraldando a bandeira da jornada de oito horas [..., $]$ os metalúrgicos deflagraram a maior greve já feita por uma categoria de trabalhadores no Rio Grande do Sul. Ficaram de braços cruzados de I3 de julho a I8 de agosto de I9I9 e só voltaram ao trabalho depois da vitória de seu movimento (MARÇAL, I985, p. 49).

No decorrer do mês de agosto, a greve dos metalúrgicos gaúchos adquiriu um caráter geral, paralisando milhares de trabalhadores de Porto Alegre. No dia 7 de setembro a polícia reprimiu violentamente um comício dos grevistas em frente à prefeitura:

No dia 7 de setembro, 5 mil dos 9 mil trabalhadores de Porto Alegre estavam em greve pacífica. [...] A polícia [...] proibiu a realização do comício planejado pelos grevistas. [...] Quando o número dos presentes se elevava a cerca de 500, irrompeu o tiroteio [...;] tropas da Brigada Militar, sob as ordens do governador, invadiram as sedes da Federação Operária, do Sindicato dos Operários da Light e da União Metalúrgica. Seus dirigentes foram desarmados e encarcerados (DULLES, 1977, p. 94-95).

\section{DIVERSAS LIDERANCASAS OPERÁRIAS SE DECLARAM “COMUNISTAS”}

A brutal repressão não conseguiu refrear a disposição de luta do movimento operário ou deter a elevação de seu nível de consciência, que, sob influência da Revolução Russa, começou a assumir novas formas. Assim, multiplicaram-se os grupos "comunistas" e "maximalistas": "Surgem novos grupos anarquistas empregando o vocábulo comunista na sua denominação. Esse foi o caso da Liga Comunista de Livramento (19I8) e do Centro Comunista de Passo Fundo (I9I8)" (PETERSEN, 1979, p. 208).

No fogo da luta, os trabalhadores trataram de avançar sua organização. Em 9 de março de I9I9, é fundado o Partido Comunista do Rio de Janeiro, aberto para "anarquistas, socialistas e todos os que aceitarem o comunismo social”. Em I6 de junho, foi criado o núcleo de São Paulo do Partido Comunista.

Em 2I de junho, iniciou-se no Rio de Janeiro a Primeira Conferência Comunista do Brasil, na verdade uma reunião de todo o movimento anarquista do país. Presentes, 22 delegados, representando "comunistas" do Distrito Federal, Alagoas, Minas Gerais, Paraíba, Pernambuco, Rio Grande do Sul e São Paulo. Devido à repressão, a conferência se reuniu nos dias 22 e 23 em Niterói. Mas o encontro se encerrou sem chegar a um acordo sobre o programa do novo partido, delegando ao grupo de São Paulo a tarefa de elaborá-lo.

Esse partido comunista possuía uma contradição insolúvel: por um lado, era formado na sua imensa maioria por "libertários" convictos; por outro, constituía-se 
em "partido" (o que era a própria negação do "apoliticismo" anarquista) e era um entusiasta defensor da Revolução Russa, na qual a classe operária havia baseado na prática as questões da "tomada do poder" e da formação de um "Estado proletário" (o que era inaceitável para a concepção anarquista). Isso só poderia levar — como levou — à sua total inoperância.

A solução dessa contradição só se deu em 1922, depois que o anarquismo diferenciou-se e cindiu-se. De um lado, os que se mantiveram fiéis ao anarquismo, contrários a toda ação política e progressivamente antissoviéticos. De outro, os que romperam com o anarquismo, aderiram ao marxismo-leninismo (apesar de incompreensões) e se mantiveram fiéis à Revolução Russa. Entre 1920 e I922, ocorreu no movimento sindical uma intensa luta ideológica entre "anarquistas" e "maximalistas" ou "comunistas", amadurecendo as condições para o surgimento de um verdadeiro partido comunista.

\section{A FALÊNCIA TEÓRICA E PRÁTICA DO ANARQQUISMO}

Em março de I920, ocorreu a greve dos trabalhadores da Leopoldina Railway - abrangendo o Distrito Federal e os estados do Rio de Janeiro e Minas Gerais - e da Companhia Mogiana de Estradas de Ferro, ambas derrotadas por uma brutal repressão.

De 2I a 25 de março de I920, realizou-se em Porto Alegre o Congresso Operário Regional do Rio Grande do Sul, durante o qual a cisão entre anarquistas e comunistas fica clara. O anarquista Friedrich Kniestedt relata:

no segundo dia o delegado dos metalúrgicos, C. Tofle, apresentou um pedido de re-
solução para que a Federação do Rio Grande do Sul declarasse sua adesão à Terceira
Internacional, em Moscou. Esse pedido foi apoiado por Abílio de Nequete e outros.
Esses senhores queriam transformar a organização puramente sindical [...] em um
campo de batalha político. [...] Mas eu consegui que essa questão ficasse para o ter-
ceiro dia e este foi fatal para os adeptos da Terceira Internacional. O pedido deles foi
rejeitado (GERTZ, I989, p. 13I).

Entre 23 e 30 de abril de 1920 - no contexto do descenso das lutas operárias - reuniu-se no Rio de Janeiro o $3^{\circ}$ Congresso da COB, com 150 delegados que representavam 39 organizações da capital federal e dos estados do Rio de Janeiro, São Paulo, Rio Grande do Sul, Pernambuco, Minas Gerais, Paraná, Espírito Santo, Mato Grosso, Pará e Amazonas (RODRIGUES, I979, p. I6I-I85).

José Elias da Silva e João da Costa Pimenta faziam parte da sua coordenação, e Astrojildo Pereira participou com direito à palavra, representando a Voz do Povo. Assim como os anteriores, o $3^{\circ}$ Congresso Operário optou pelo "método federativo", tão apreciado pelos libertários. A filiação à Internacional Comunista foi descartada, por não ser esta "uma organização genuinamente sindical", e o $3^{\circ}$ Congresso limitou-se a 
enviar-lhe uma moção de "congratulações". Em vez de se confiarem suas resoluções à $\mathrm{COB}$, foi criada uma comissão executiva do $3^{\circ}$ Congresso, tendo um secretário-geral — Edgard Leuenroth - um tesoureiro e cinco secretários itinerantes, entre eles José Elias, que pouco depois assumiu a secretaria-geral, devido à enfermidade de Leuenroth (DULLES, I977, p. Io8-II6).

Após o $3^{\circ}$ Congresso Operário Brasileiro, ocorreu um desmantelamento das organizações operárias e de sua imprensa. Contribuiu para isso a forte repressão policial, as leis antianarquistas, o desemprego e a incapacidade do anarquismo em dar respostas corretas às exigências da nova fase de lutas que se iniciava:

As grandes greves e agitações de massa do período 1917-1920 puseram a nu a incapacidade teórica, política e orgânica do anarquismo para resolver os problemas de direção de um movimento revolucionário de envergadura histórica, quando a situação objetiva do país (em conexão com a situação mundial criada pela guerra imperialista de I9I4-I9I8 e pela vitória da revolução operária e camponesa na Rússia) abrira perspectivas favoráveis a radicais transformações na ordem política e social dominante. A constatação desse fato [...] levou diretamente à organização dos primeiros grupos comunistas [...,] passo inicial para a formação do Partido Comunista (PEREIRA, I976, p. 5I-52).

Em outubro de I9I9, fracassou outra greve geral em São Paulo, liderada pelos anarquistas. Diversos trabalhadores foram presos e despedidos, outros, deportados para o exterior ou outros estados. O anarquismo deixava claros os seus limites enquanto concepção orientadora da luta dos trabalhadores:

a recusa em considerar a organização necessária ao proletariado para a luta política contra o Estado; a negativa em organizar a classe em partido próprio, com vistas à tomada revolucionária do poder; o apego absoluto à chamada "resistência anticapitalista", que se traduzia na superestimação do papel do sindicato e da luta econômica; a exaltação das formas espontâneas de luta, de ações voluntaristas e heroicas, individualizadas e desvinculadas das massas; enfim, esses aspectos da teoria e prática dos anarquistas, revelaram o impasse e o beco sem saída a que foi levado o movimento operário no Brasil nesse final dos anos Io [...; ] as ações do movimento anarquista não superaram a espontaneidade economicista (SEGATTO, I987, p. 85-86).

No final de I920, início de I92I, ainda ocorreram algumas greves, como a dos estivadores de Santos e dos marítimos do Rio de Janeiro, com o apoio dos trabalhadores marítimos do Recife e do sul do país. A sede da União dos Operários da Construção Civil do Rio de Janeiro - que preparava uma greve geral de solidariedade aos marítimos - foi invadida e diversos operários foram presos, após um conflito armado. O fracasso dessa greve geral intensificou o refluxo do movimento operário:

$\mathrm{O}$ ano doloroso da vazante foi I92I. Os trabalhadores estavam vencidos. Nos sindicatos, reduzidos a esqueleto, ficou apenas uma pequena vanguarda. Essa vanguar- 


\section{Em 1921, surgiu no Rio de Janeiro o Grupo Clarté, defensor da Revolução Russa, do qual faziam parte Everardo Dias, Cristiano Cordeiro, Joaquim Pimenta, Afonso Schmidt, Lima Barreto, Agripino Nazareth, Leônidas Resende, Evaristo de Moraes, Pontes de Miranda, Paulo de Lacerda, Maurício de Lacerda e Antônio Figueiredo}

da continuou a defender os ideais da luta proletária. Meditou nas lições da derrota. Compreendeu que a maior parte da culpa cabia às ideias e aos métodos anarquistas e anarcossindicalistas. Compreendeu que eram necessários nova ideologia e novos métodos. [...] No seio da classe operária predominavam, então, duas correntes. Uma, oportunista de "esquerda", com o anarquismo e o anarcossindicalismo. A outra, oportunista de direita [..., com o reformismo apodrecido e policial [...; os anarquistas e anarcossindicalistas não poderiam triunfar. Nem dirigir nenhuma revolução. Faltava-lhes o conhecimento das noções preliminares. Quais? A teoria da luta de classes. A necessidade do Estado proletário, de transição. $\mathrm{O}$ estudo da situação objetiva. A análise da correlação de forças em cada momento dado. [...] Os avanços e recuos. A ofensiva e a defensiva. A luta legal e a ilegal. A luta no parlamento e a luta extraparlamentar. A combinação dessas formas de luta e de muitas outras. [...] $\mathrm{O}$ anarquismo pregava a revolução. Mas não tinha nenhuma ideia concreta da revolução. Não compreendia suas etapas. Nem suas forças motrizes. Nem o papel do proletariado. Nem a aliança com os camponeses. Reduziu, de fato, a luta dos operários à luta econômica e sindical. [...] O anarquismo era uma corrente individualista pequeno-burguesa. Não admitia nenhum partido. Negava, de fato, a política [...]. Não tinha disciplina. Nem organização (BRANDÃO, 1978, p. 209-210).

Apesar das limitações do anarcossindicalismo, a avaliação cuidadosa do seu papel nos faz concordar com a opinião do historiador soviético Boris Koval:

Diferentemente do anarquismo clássico (bakunismo) o anarcossindicalismo adotou algo do marxismo (o ensinamento sobre a luta de classes) [...] e apoiava-se nos sindicatos, como forma fundamental de organizações da luta proletária. [...] Assim, no final do século XIX, início do século XX, surgiu [...] no movimento operário uma nova 
corrente combativa - o sindicalismo revolucionário, que na prática era a encarnação da luta proletária nos limites da forma ideológica pequeno-burguesa. Desde os primeiros dias de seu surgimento o sindicalismo revolucionário levou a uma rápida animação do movimento operário e antes de mais nada da luta grevista, dando uma contribuição essencial à formação dos sindicatos. [...] A atuação dos operários tornou-se mais consciente e organizada, fortaleceu-se o sentimento de solidariedade de classe, em vários casos chegou-se a choques armados com a polícia e tropas. [...] Livre da influência direta do oportunismo da II Internacional, a classe operária do Brasil deu sua contribuição à luta das forças internacionalistas de esquerda, encabeçadas pelos bolcheviques russos, contra o social-chauvinismo e o capitulacionismo [...; pode-se concluir que antes do surgimento da corrente marxista e da fundação do Partido Comunista o sindicalismo revolucionário desempenhou um papel positivo [...] não se transformou imediatamente em freio no caminho do desenvolvimento do movimento operário. Inicialmente, os sindicalistas exerceram uma influência até mesmo positiva, despertando os operários para a tomada de consciência do novo regime explorador burguês, para a luta (ainda que espontânea e limitada) por seus direitos econômicos e políticos. Durante anos, os sindicalistas foram, no Brasil, a única força revolucionária a conclamar o proletariado à luta e a dirigir essa luta. [...] Desse ponto de vista, o sindicalismo revolucionário no início do século XX desempenhou no Brasil um papel positivo, ativando a luta do proletariado e desse modo contribuindo para sua formação como classe independente. (KOVAL, I982, p. 99-II8).

Entretanto, ou a classe operária brasileira avançava, ou sofreria uma derrota histórica. Ela tratou de avançar.

\section{A FUNDAÇ̃̃o dO PARTIDO COMUNISTA dO BRASIL}

O exame cuidadoso do surgimento do PC do Brasil nos leva a rejeitar a visão simplista dos que veem a sua criação como algo alheio ao amadurecimento objetivo da vanguarda operária brasileira e da luta de classes e como uma criação artificial da Internacional Comunista e do "dedo de Moscou".

Em primeiro lugar, é inegável que o surgimento do Partido Comunista do Brasil esteve diretamente ligado às grandes mobilizações operárias de 1917-I920 e à sua derrota, causada pela incapacidade da liderança anarquista em dar um rumo correto a essas lutas.

Foi nesse contexto de impotência e de fracasso do anarquismo na condução da luta contra a exploração capitalista que eclodiu a Revolução Russa, dirigida pelo Partido Bolchevique, a qual conduziu o proletariado ao poder, em aliança com o campesinato. A influência desse acontecimento sobre a vanguarda operária brasileira foi enorme. Os "dogmas" anarquistas contra o "partido em si" e contra o "Estado em si" - sem ter em conta o seu caráter de classe - caíram por terra! 
Aos poucos, se deu um processo de diferenciação no movimento anarquista, em que cresceu a corrente anarcobolchevista, da qual saíram diversos fundadores do PC do Brasil em I922. A passagem de uma parte dos líderes anarquistas para o campo do antissovietismo também acelerou esse processo.

Um terceiro fator fundamental para o surgimento do Partido Comunista foi o crescimento e a concentração da classe operária, por conta da aceleração da industrialização do país durante a Primeira Guerra Mundial. Segundo o censo de I920, o operariado industrial brasileiro chegava a 300 mil trabalhadores. Se a eles acrescentamos os assalariados em transporte, comércio, serviços portuários etc., chegaremos a cerca de I milhão de proletários urbanos no Brasil, à época. Os três estados de maior concentração proletária eram São Paulo (28,3\%), Rio de Janeiro $(24,6 \%)$ e Rio Grande do $\operatorname{Sul}(8,3 \%)$.

A classe operária era composta principalmente por trabalhadores da indústria têxtil $(40,7 \%)$ e alimentícia (I8,8\%), somando quase $60 \%$ dos operários. Desses, I3\% estavam em empresas com até nove operários, I7\%, em empresas com dez a 49 operários, e 70\%, em empresas com 50 ou mais operários. No Rio de Janeiro, trabalhavam em empresas com mais de cem operários 67\% do total; em São Paulo, 64\%; no Rio Grande do Sul, 52\%. O que nos mostra que boa parte da classe operária brasileira já era de fato fabril:

É também interessante comparar o nível de concentração da classe operária no Brasil e na Rússia czarista, especialmente a porcentagem de trabalhadores ocupados nas empresas com mais de cem operários cada [uma]: na Rússia de I9Io - 80\%; no Brasil de $1920-61,1 \%$. Mas isso ainda não significa que na Rússia o grau de concentração do proletariado era superior [...;] o grau de concentração do proletariado industrial no Brasil era consideravelmente superior: o número médio de operários nas empresas desse grupo na Rússia era de 53 operários, e no Brasil, 33I, ou seja, seis vezes maior (KOVAL, 1982, p. 130).

No Rio Grande do Sul, é preciso considerar ainda a influência dos movimentos operários da Argentina e do Uruguai, onde os partidos comunistas foram criados em I9I8 e 1920, respectivamente. Lá os PCs surgiram de fortes partidos socialistas, diferentemente do Brasil. Em uma fronteira permeável ao contrabando e à migração, eram comuns a circulação de ideias e de publicações marxistas e as ações de solidariedade proletária:

Em Rio Grande [Abílio de Nequete] encontrou vários endereços do exterior e alguma bibliografia. De volta a Porto Alegre escreveu a Buenos Aires, de onde recebeu o semanário Internacional e Documentos del Progreso, e através desses encontrou vários livros. Assim, através da viagem recomendada pelos anarquistas, Abílio de Nequete encontrou bibliografia preciosa para o seu objetivo de convencer os camaradas a se afastarem do anarquismo (ROSITO, I972, p. 8). 
Em 1917, foi criada pelo eletricista Hermogêneo da Silva, na cidade de Cruzeiro, São Paulo, a União Operária I $^{\circ}$ de Maio, que existiu até o congresso de fundação do Partido Comunista do Brasil, em I922, no qual Hermogêneo foi um dos nove delegados. Também no Rio Grande do Sul surgiram diversos grupos "comunistas":

em I9I8, aos 28 anos de idade, Santos Soares fundou [a,] e se colocou à frente da Liga Comunista de Livramento. Essa foi a primeira organização comunista do Rio Grande do Sul. A primeira medida da liga foi publicar um jornal, que efetivamente circulou em vários números e foi disputado pelos trabalhadores. A sede da liga comunista foi assaltada pela polícia. Mas ela existiu até a fundação do Partido Comunista do Brasil, em I922. [...] A fundação da Liga Comunista de Santana do Livramento não foi um fato isolado. Com pequena diferença de tempo, surgem organizações semelhantes em diversos pontos. Funda-se um centro em Passo Fundo. [...] Os trabalhadores de Rio Grande inscrevem na fachada da União Operária o lema "Operários de todos os países, uni-vos" [...]. Essa iniciativa de fundar ligas e círculos comunistas é uma demonstração da necessidade que os trabalhadores sentem do partido. A atuação de Santos Soares está na própria raiz da organização do partido comunista no Rio Grande do Sul (MARÇAL, I986, p. I2O-I2I).

Em 19I8, Abílio de Nequete — um dos dirigentes da greve de I9I7 —, Francisco Merino e Otávio Hengist criaram a União Maximalista de Porto Alegre, que, diz Astrojildo Pereira, foi o primeiro grupo comunista do Brasil: "A mais antiga dessas organizações era a União Maximalista, de Porto Alegre, fundada em I9I9 [sic] e que em I92I, atendendo ao apelo do grupo carioca, converteu-se no Grupo Comunista de Porto Alegre e como tal contribuiu em larga medida para a fundação do partido" (PEREIRA, I976, p. 7I).

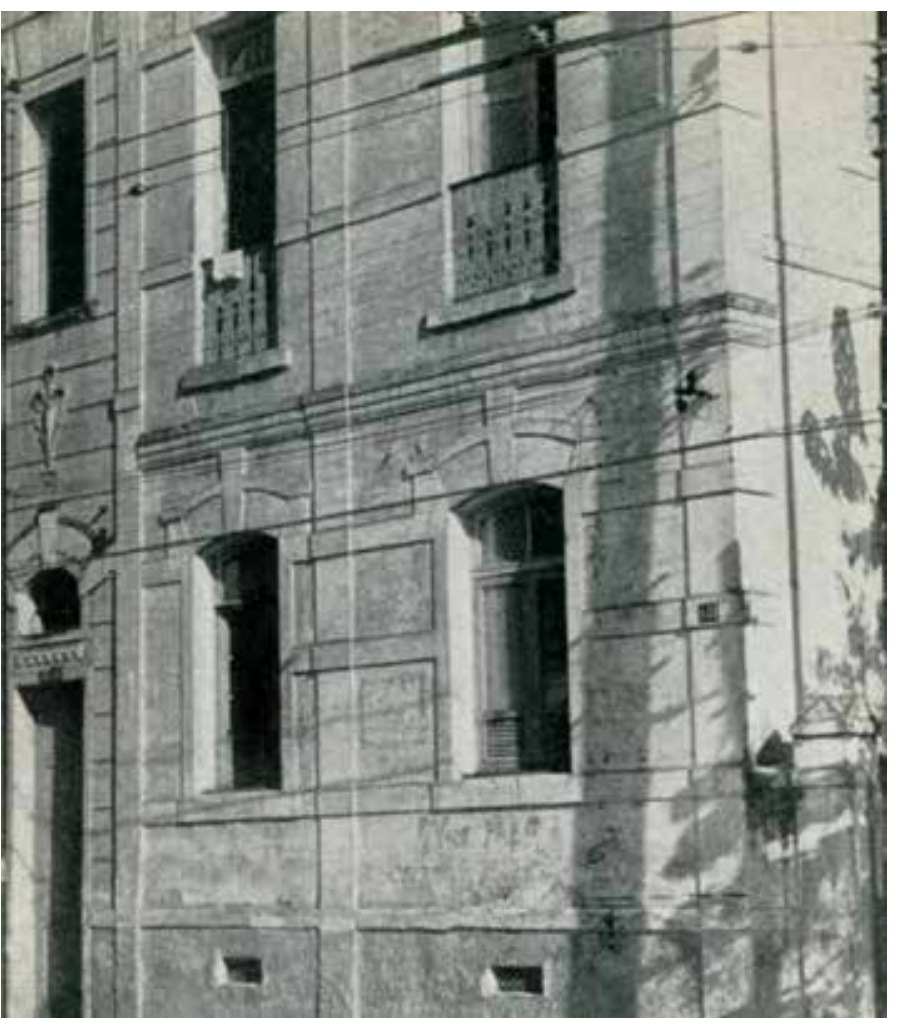

4 Casa na rua Visconde do Rio Branco, número 651, Niterói (RJ), onde ocorreu a $3^{\mathrm{a}}$ sessão do $1^{\circ}$ Congresso do Partido Comunista, em 27 de Março de 1922

Capa dos primeiros estatutos do Partido Comunista

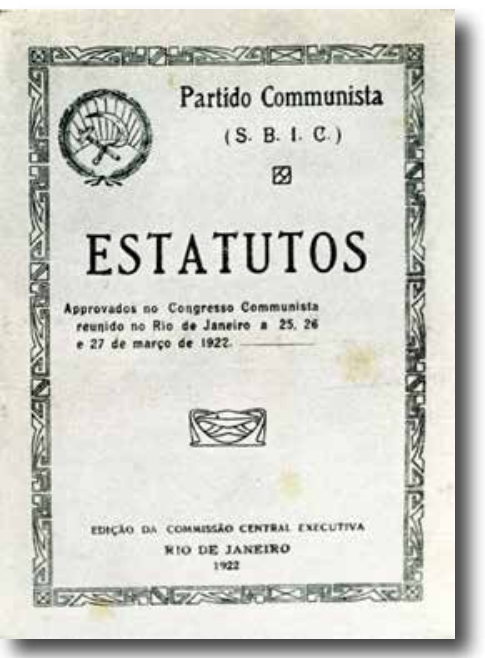


Em I ${ }^{\circ}$ de novembro, a União lançou o seu "Manifesto aos operários":

Operários! Invadi essas casas arejadas e habitai-as sem discussão, porque foram construídas por vossas próprias mãos. Destruí, duma vez para sempre, o capricho dessa corrompida sociedade, que tem por objetivo aniquilar-vos. Apoderai-vos desses depósitos de produtos alimentícios e alimentai-vos deles sem receio, porque eles são o produto de vosso labor, são portanto legitimamente vossos e não de seus atuais detentores, vossos fidagais [figadais] inimigos, os quais há séculos consomem sem produzir coisa alguma. - Ponhamo-los fora de nossa comunhão, só lhes [os] aceitando quando se apresentassem [se apresentem] como de fato produtores. Operários!, apoderai-vos de tudo o que encontrardes depositado em tecidos e calçados e vesti-vos, porque se não fora as vossas mãos, nada disso haveria. Operários!, mais um impulso e a burguesia do mundo cairá. Tende em mira o impulso "maximalista", bastando ali a vontade dos operários e soldados, para pôr por terra não só a secular tirania dos Romanovs como também seu satélite, a democracia kerenskina. Operários!, basta de indolência, saibas [sabei] de uma vez para sempre que o mundo só deve ser daqueles que produzem; e todo aquele que não produz é parasita [...]. Operários!, vós unidos derrubareis esse carcomido edifício da burguesia, edificando em seu lugar o da razão, da harmonia e da igualdade, que consiste em cada qual dar o que pode, levando o que necessita. Operários!, [...] o maximalismo era triunfante na Rússia e, segundo as últimas informações, já está invadindo os impérios centrais, começando pela Bulgária, já bate no trono dos Hohenzollern... Estejais [Estai] pois alertas, porque ele há de vir até cá... muito breve talvez, a despeito de todos os arreganhos... (BANDEIRA, I980, p. 336-338).

Em 1919, foi criado, em São Paulo e Rio de Janeiro, o Grupo Comunista Brasileiro Zumbi, do qual participava o escritor Afonso Schmidt. Nesse mesmo ano, surgiu o Núcleo Comunista de Pelotas, de orientação anarquista. Em I920, foram fundados em Porto Alegre o Sindicato Gráfico Comunista e na cidade de Rio Grande a União Comunista, ambos de orientação anarquista.

Em I92I, surgiu no Rio de Janeiro o Grupo Clarté, defensor da Revolução Russa, do qual faziam parte Everardo Dias, Cristiano Cordeiro, Joaquim Pimenta, Afonso Schmidt, Lima Barreto, Agripino Nazareth, Leônidas Resende, Evaristo de Moraes, Pontes de Miranda, Paulo de Lacerda, Maurício de Lacerda e Antônio Figueiredo. Desses, só os três primeiros participarão da fundação do PC do Brasil.

No dia 7 de novembro de I92I, foi fundado o Grupo Comunista do Rio de Janeiro, formado por I2 pessoas: Astrojildo Pereira, Luís Perez, José Alves Diniz, Antônio de Carvalho, Antonio Branco, Antônio Cruz Júnior, Aurélio Durães, Francisco Ferreira, João Argolo, Manuel Abril, Olgier Lacerda e Sebastião Figueiredo. De imediato, entraram em contato com outros grupos operários, divulgando as 2I cláusulas da Internacional Comunista e recomendando que também formassem grupos "comunistas". 
Logo surgiram grupos semelhantes no Recife, Juiz de Fora, Santos e Cruzeiro (SP). Em I ${ }^{\circ}$ de janeiro de I922, Cristiano Cordeiro - que entre I9I9 e 1920 havia criado no Recife, com Rodolfo Coutinho, o Círculo de Estudos Marxistas - fundou o Grupo Comunista do Recife:

Correspondi-me em I92I com Astrojildo Pereira [...]. Combinamos criar, ele no Rio, eu no Recife, embriões de futuros comitês do partido. [...] O Grupo Comunista do Recife estabeleceu-se no dia I $^{\circ}$ de janeiro de 1922. [...] Li, na ocasião, os chamados "2I pontos de Moscou", condições para adesão à Internacional Comunista. A ata de fundação foi assinada por cerca de 35 pessoas que decidiram, ainda, que eu seria o delegado de Pernambuco ao encontro para a criação do PCB (BARROS, 1982, p. 83).

Em janeiro de I922, o Grupo Comunista do Rio de Janeiro lançou a revista Movimento Comunista, "órgão dos grupos comunistas do Brasil", para "defender e propagar, entre nós, o programa da Internacional Comunista [....] repositório mensal fidedigno de doutrina e informação do movimento comunista internacional." (BANDEIRA, I980, p. 275). A revista - que depois se tornou o órgão oficial do PC do Brasil — publicou I3 números em I922, totalizando 390 páginas, com uma tiragem total de 15 mil exemplares. Em I923, foram publicados outros I2 números, sendo o último datado de io de junho.

No início de 1922, Astrojildo foi até São Paulo, com o objetivo de fundar um grupo comunista, mas só conseguiu que meia dúzia de pessoas assinassem o livro de presença. Quanto ao Rio Grande do Sul:

Em fins de 192I, Astrojildo Pereira, do Grupo Comunista do Rio de Janeiro, escrevera a Polidoro Santos (anarquista da Liga de Defesa Popular) pedindo a sua adesão à Revolução Russa. Polidoro respondera informando o endereço de Abílio de Nequete, solicitando que se dirigisse a ele. Dessa correspondência resultou a mudança do nome de União Maximalista para Grupo Comunista, "mais de acordo com o que Lênin havia proposto" [Nequete]. [...] No início de 1922, Abílio de Nequete recebe um telegrama do Uruguai, dizendo que a sua presença era exigida naquele país por um assunto urgente. O telegrama era assinado por Martin Simoni e tinha resposta paga. Recebeu o dinheiro para a viagem, depois de responder afirmativamente. No Uruguai [...,] procurou Simoni na redação de Justicia. Foi informado da intenção de um delegado russo vir ao Brasil e da necessidade de entrarem em contato. $\mathrm{O}$ delegado russo era Alexandre Alexandrovski, que tinha ido à Rússia nos primórdios da revolução em nome dos russos residentes na Argentina, e voltara como delegado da revolução para a América Latina. Desejava obter um relatório sobre o movimento brasileiro e a organização do partido. Dali regressaria à Rússia. Em Buenos Aires, R. Vaterland, outro delegado da revolução, deveria continuar a correspondência. Ficou estabelecido que Abílio de Nequete iria ao Rio de Janeiro convocar um congresso, embora de poucos elementos, já que a insistência de Alexandrovski devia-se à falta do nome do Brasil na Internacional. Depois de mais alguns dias em Montevidéu, Abílio de Nequete voltou 
a Porto Alegre, de onde escreveu a Astrojildo Pereira e Everardo Dias, informando da próxima viagem ao Rio e remetendo o jornal Justicia [...; foi Abílio de Nequete quem recebeu, do delegado russo, a incumbência de organizar o partido, devido à necessidade de enviar um representante do Brasil ao IV Congresso da Internacional de Moscou. O Grupo Comunista de Porto Alegre já estava reconhecido pela Internacional, embora tivesse apenas I2 membros (ROSITO, I972, p. IO-II).

Em I922, a União Maximalista — já com a denominação de Grupo Comunista - tinha I2 membros: "Nequete, Francisco Merino, Otávio Hengist, Carlos Toffolo, Narciso Mirandola, um judeu argentino - Samuel Speiski - e mais dois judeus, Marcos e Isaac. Não há referência quanto aos outros quatro membros, a não ser um português - Magalhães" (ROSITO, I972, p. Io):

Encontrando, no início do ano de 192I, o diário Justicia, órgão do Partido Socialista Uruguaio, tomou conhecimento da preparação do congresso em que esse partido deveria aderir a Moscou. [...] Por ocasião do aparecimento das 2I condições, no II Congresso Internacional de Moscou, reuniu-se novamente o Partido Socialista Uruguaio. Ab́lio de Nequete escreveu ao deputado Mibelli pedindo que aceitasse as condições e concedendo-lhe a representação da União Maximalista do Rio Grande do Sul - "eis como Mibelli teve de ser o primeiro representante do Brasil num congresso comunista" [Nequete]. Na mesma carta escrevera a frase de Barbusse [...] sobre as 2I condições: "Nada tinha que não pudesse ser aceito por um socialista sincero ou cidadão honesto". O presidente daquela sessão do congresso telegrafou mais tarde agradecendo à União Maximalista do Rio Grande do Sul. Foi a primeira relação da União com o exterior (ROSITO, I972, p. 9).

Finalmente, entre 25 e 27 de março de I922, foi realizado (no Rio de Janeiro nos dias 25 e 26, na sede de uma união operária, e no dia 27 em Niterói, na residência do pai de Astrojildo, na rua Visconde do Rio Branco, nº 65I) o congresso de fundação do Partido Comunista do Brasil:

Em meados de fevereiro, por iniciativa dos camaradas do Grupo de Porto Alegre, o Grupo do Rio entendeu-se com os demais grupos existentes sobre a necessidade de se apressar a reunião, em congresso, dos delegados dos mesmos, para definitiva organização do partido em vista da aproximação do IV Congresso da Internacional de Moscou, no qual deveriam fazer-se representar os comunistas do Brasil (PEREIRA, I976, p. 65).

Estavam presentes nove delegados, representando 73 filiados em todo o país: Abílio de Nequete, barbeiro, de Porto Alegre, que também representava o Partido Comunista do Uruguai e a Agência de Propaganda para a América do Sul da Terceira Internacional; Astrojildo Pereira, jornalista, de Niterói; Cristiano Cordeiro, funcionário público, do Recife; Hermogêneo Fernandes da Silva, eletricista e ferroviário, de Cru- 

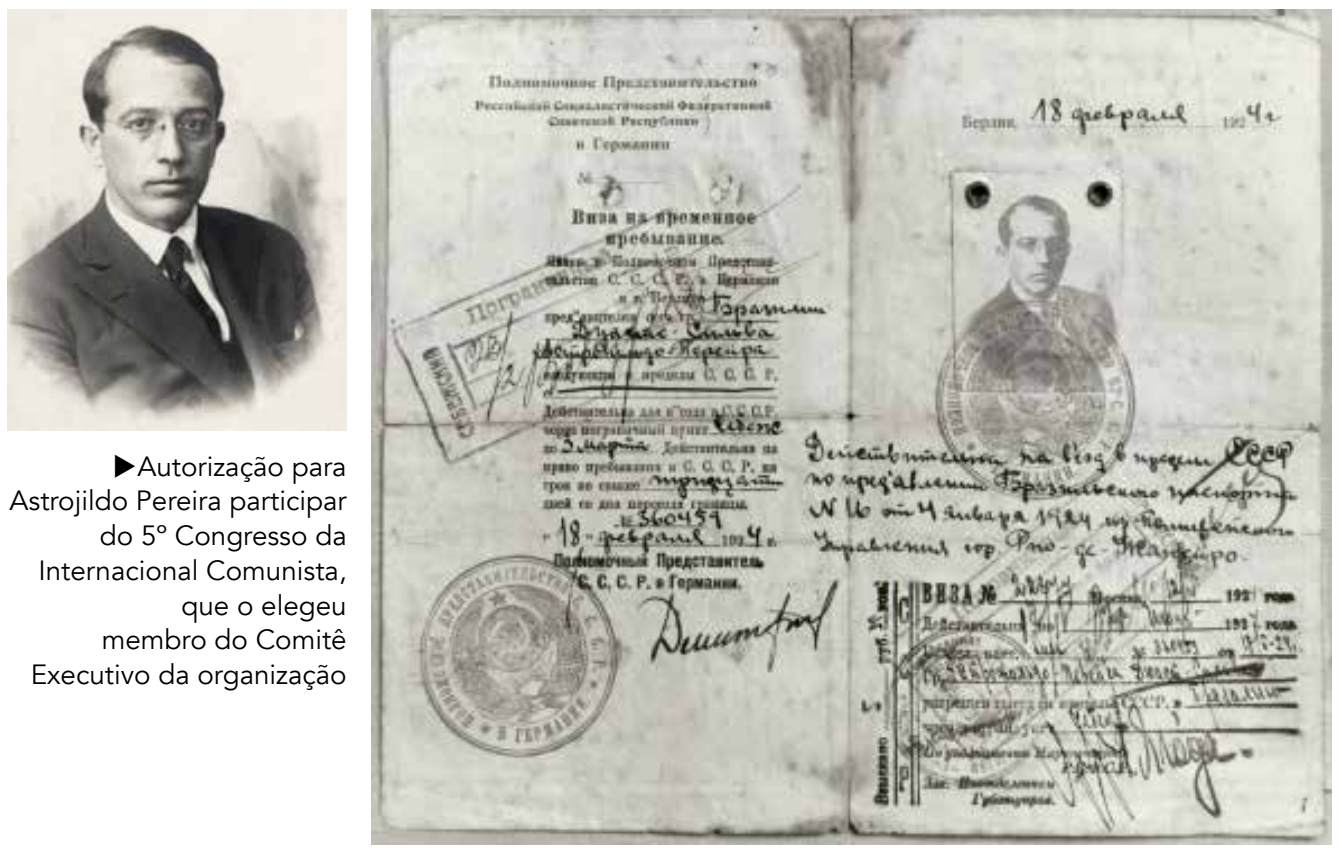

zeiro; João Jorge da Costa Pimenta, gráfico, de São Paulo; Joaquim Barbosa, alfaiate, do Rio de Janeiro; José Elias da Silva, funcionário público, do Rio de Janeiro; Manoel Cendón, artesão alfaiate; Luís Perez, artesão vassoureiro, do Rio de Janeiro. Desses, sete eram brasileiros natos, um espanhol (Cendón) e um libanês (Nequete). Os grupos comunistas de Santos e Juiz de Fora não puderam enviar delegados.

Da pauta do I $^{\circ}$ Congresso constavam: I) exame das 2I condições de admissão na Internacional Comunista; 2) estatutos do Partido Comunista; 3) eleição da Comissão Central Executiva; 4) ação pró-flagelados do Volga; 5) assuntos vários. Depois de aceitas as 2I condições da IC, os presentes aprovaram estatutos provisórios, baseados nos estatutos do PC da Argentina: "Antes da instalação do Congresso, Abílio de Nequete recebeu os estatutos do Partido Comunista da Argentina e uma mensagem de R. Vaterland [...]. O número 7 da revista Movimento Comunista publicou a mensagem de R. Vaterland, secretário do Bureau Internacional Comunista." (ROSITO, 1972, p. I2) Os estatutos dispunham:

Art. I $^{\mathrm{o}}$ - Fica fundada, por tempo indeterminado, uma sociedade civil, no Rio de Janeiro, ramificando-se por todo o Brasil, tendo por título Centro do Partido Comunista do Brasil, mas que será chamada Partido Comunista, Seção Brasileira da Internacional Comunista.

Art. $2^{\circ}$ - O Partido Comunista tem por fim promover o entendimento e a ação internacional dos trabalhadores e a organização política do proletariado em partido de classe para a conquista do poder e consequente transformação política e econômica da sociedade capitalista em sociedade comunista (CARONE, 1982, p. 23). 
Como se constata, o PC nasceu com o nome de Partido Comunista do Brasil, que conserva até hoje, não tendo registrado qualquer sigla. Depois de algum tempo, ficou conhecido como PCB. Em agosto de I96I - quando o então Comitê Central criou o chamado Partido Comunista Brasileiro, os militantes e dirigentes que permaneceram fiéis ao partido de 1922 reorganizaram, em fevereiro de I962, o Partido Comunista do Brasil, adotando a sigla PCdoB para se diferenciar do novo partido recém-criado. Ou seja, de 1922 a I962, durante 40 anos, o Partido Comunista do Brasil foi conhecido pela sigla PCB. E de 1962 até os dias de hoje, por quase 60 anos, pela sigla PCdoB.

Depois de aprovados os estatutos, foi eleita a primeira Comissão Central Executiva, composta por cinco titulares e cinco suplentes; como titulares foram escolhidos Abílio de Nequete, secretário-geral; Astrojildo Pereira, secretário de imprensa e publicidade; Antonio Bernardo Canellas (gráfico), secretário internacional; Luís Perez, secretário de frações sindicais; e Antônio Gomes Cruz Júnior (comerciário), tesoureiro. Os suplentes eleitos foram Cristiano Cordeiro, Rodolfo Coutinho (estudante), Joaquim Barbosa, Manoel Cendón e Antonio de Carvalho (estivador). A maioria deles era originária do anarcossindicalismo, com exceção de Manoel Cendón - influenciado pelos socialistas da Argentina, onde vivera - e Rodolfo Coutinho.

Abílio de Nequete foi eleito secretário-geral por indicação de Astrojildo Pereira, possivelmente pela maior antiguidade da União Maximalista e pelo seu contato com o Partido Comunista Uruguaio e com o Bureau da IC para a América Latina, mas logo demonstrou estar pouco preparado para a função.

As demais discussões foram sobre mensagens, moções e medidas em solidariedade aos flagelados russos. Não foi aprovado nenhum documento de análise da realidade ou de orientação política.

Não havendo lei específica para os partidos políticos, o PC do Brasil foi registrado como sociedade civil e seus estatutos foram publicados na página 6.970 do Diário Oficial da União de 7 de abril de 1922.

Se, por um lado, a criação do PC do Brasil foi um enorme salto de qualidade da classe operária brasileira - sua transformação de classe em si para classe para si por outro lado, teve diversas debilidades.

Primeiro, porque - apesar de surgir no bojo da avaliação da rica experiência das lutas de I9I7-I920 e da crítica ao anarquismo - o partido se formou em um momento de refluxo do movimento operário e de dura repressão governamental. Em segundo lugar, pelo grande desconhecimento do marxismo no nosso país, seja na classe operária, seja na intelectualidade progressista. Em terceiro lugar, pela falta de maior tradição organizativa no movimento operário, fruto de longo predomínio anarquista e da debilidade das correntes socialistas, com consequências negativas para a tarefa de organizar um partido coeso e disciplinado.

A essas dificuldades é preciso acrescentar o relativo atraso industrial do país, a origem rural de boa parte da classe operária, o "apoliticismo" incutido anos a fio na sua mentalidade e o forte peso das correntes reformistas (católicas, cooperativistas, 
socialistas reformistas) no movimento operário:

Mas a classe operária, ao fundar seu partido, é ainda bastante jovem. Somente durante a I Guerra Mundial o capitalismo no Brasil adquire maior impulso. Expande-se a indústria leve, particularmente o ramo têxtil, e se ampliam os meios de transporte marítimo e ferroviário. Junto com a burguesia se desenvolve o proletariado, que vende sua força de trabalho não só a capitalistas nacionais como também a empresas imperialistas. A classe operária se compõe em boa parte de elementos provindos do campo e de trabalhadores de oficinas e pequenas empresas [...]. O movimento sindical, ainda que combativo, apresenta muitas debilidades. O proletariado mal começa a adquirir consciência política. [...] Até então, o marxismo não é conhecido no Brasil e, mesmo entre a intelectualidade avançada, prevalece o anarquismo. Tudo isso não pode deixar de repercutir no partido recém-fundado, que reflete as virtudes e os defeitos da classe operária. Apesar de ter surgido sob a égide da III Internacional [...,] o partido pouco conhece o marxismo e muito longe está de dominá-lo. Falta-lhe suficiente clareza para se orientar com acerto na realidade (PARTIDO COMUNISTA DO BRASIL, 1972, p. 5).

\section{OS PRIMEIROS COMBATES}

Não por coincidência, o ano de 1922 foi marcado por outros dois acontecimentos históricos.

De I3 a I7 de fevereiro, aconteceu em São Paulo a Semana de Arte Moderna, que revolucionou a vida cultural do país, rompeu os velhos cânones artísticos e refletiu o momento de rupturas que o país vivia.

Três meses depois, em 5 de julho, eclodiu o levante do Forte de Copacabana, iniciando o assim chamado "ciclo tenentista", reflexo entre os militares da crescente insatisfação da pequena burguesia urbana e de setores da própria burguesia com a República Velha. A partir de então, o movimento tenentista marcará, durante muitos anos, a sua presença na vida política brasileira:

$\mathrm{O}$ ascenso do revolucionarismo pequeno-burguês, que nos anos 20 adquiriu significado nacional, exerceu enorme influência ideológica sobre todas as camadas da sociedade brasileira. A influência do tenentismo condicionou uma série de particularidades do desenvolvimento ulterior da classe operária e da atividade do jovem Partido Comunista. O revolucionarismo espontâneo pequeno-burguês, encarnado no tenentismo, foi resultado natural da atmosfera socioeconômica e política em que se desenvolvia o país depois da abolição da escravatura [...]. Não foram concluídas as transformações burguesas democráticas dentro do país [...]. O imperialismo estrangeiro [...] e a grande propriedade latifundiária eram o principal obstáculo no caminho do progresso social e desenvolvimento econômico do Brasil. [...] Nesse sentido, os interesses da classe operária coincidiam com as posições da democracia pequeno-burguesa [...]. Entretanto, não havia no país força capaz de acabar, de forma revolucionária, com a oligarquia latifundiária. A burguesia nacional comercial, e em seguida a industrial, 
entrava em aliança com os latifundiários. No que se refere às organizações operárias, estas, durante longo tempo, não concederam, de um modo geral, séria atenção ao problema agrário. [...] Em consequência, o proletariado e o campesinato atuavam isolados um do outro. [...] A luta dos camponeses brasileiros não podia triunfar enquanto eles permanecessem isolados, sem uma verdadeira direção revolucionária. A pequena burguesia urbana foi quem primeiro tentou desempenhar o papel dessa direção nos anos 20 (KOVAL, I982, p. I69-I70, I75-I76).

Nessa época, os comunistas ainda primavam pelo sectarismo e pela falta de uma maior visão política:

O PCB realizava pequenas reuniões para seus membros. Nelas, os problemas gerais internacionais ocupavam todo o tempo. Os problemas do Brasil eram esquecidos. Um "comunismo" de importação, voltado para a Europa. Os comunistas de 1922 não sabiam ligar as questões concretas da vida e da luta no país [...] com os problemas concretos internacionais. [...] Débil, sectário, o PCB não compreendeu a situação política de 1922. Limitou-se a uma posição passiva em face dos revoltosos da insurreição armada de Copacabana, a 5 de julho de 1922. Continuou sua vida tranquila. Não compreendeu que era preciso passar à vida ilegal, clandestina, subterrânea. Não compreendeu que se abria nova etapa no processo do desenvolvimento do país. A pequena burguesia urbana, com seus revoltosos, ia levantar a cabeça. Pretendia aproveitar a debilidade do proletariado. Candidatava-se à hegemonia - uma hegemonia utópica e objetivamente reacionária. [...] Então, a 25 de julho de 1922, a polícia política do governo Epitácio Pessoa pegou de surpresa o PCB. Desencadeou contra ele a primeira perseguição. Assaltou e fechou sua sede. Prendeu I3 comunistas, entre os quais o secretário-geral e outros membros da Comissão Central Executiva. Insultou e ameaçou os presos. Confiscou muitos materiais de propaganda (BRANDÃO, I978, p. 226-227).

Desde seu surgimento, o PC do Brasil sofreu a mais furiosa repressão das classes dominantes. Em resposta à rebelião dos “tenentes”, Epitácio Pessoa decretou o estado de sítio no Distrito Federal e no estado do Rio de Janeiro. Apesar de o PC estar alheio aos acontecimentos, a polícia aproveitou para invadir e fechar a sua sede - situada em um sobradinho na praça da República no 40 , esquina com a rua da Constituição, na capital federal - e para colocá-lo na ilegalidade, três meses após a sua fundação. Solto no dia seguinte à sua prisão e ameaçado pela polícia, Abílio de Nequete desertou das funções partidárias e voltou a Porto Alegre. Algum tempo depois, foi expulso do partido. Astrojildo Pereira o substituiu na secretaria-geral, função que exerceu até novembro de I930, com um interregno em I929, quando passou quase um ano em Moscou.

Convocado o $4^{\circ}$ Congresso da IC para fins de I922, a direção do PC indicou Antonio Canellas - que estava na Europa desde I9I9 - para representá-la nesse congresso e solicitar a admissão do partido na IC. Impregnado de ideias reformistas e 


\section{Não por coincidência, o ano de 1922 foi}

marcado por outros dois acontecimentos históricos. De 13 a 17 de fevereiro, aconteceu em São Paulo a Semana de Arte Moderna, que revolucionou a vida cultural do país, rompeu os velhos cânones artísticos e refletiu o momento de rupturas que o país vivia. Três meses depois, em 5 de julho, eclodiu o levante do Forte de Copacabana

anarquistas, Canellas deixou péssima impressão na liderança da IC, que rejeitou a filiação do PC do Brasil, só o aceitando como partido simpatizante. De volta ao Brasil, o relatório de Canellas foi submetido à direção e severamente criticado. Como Canellas tornou público o seu relatório, acabou expulso do partido, em fins de i923. Só em abril de 1924 o PC do Brasil foi admitido na IC, depois que o comunista argentino Rodolfo Ghioldi veio ao Brasil, em nome da Comissão Executiva da IC, para verificar pessoalmente a situação. Rodolfo Coutinho foi designado representante do partido em Moscou.

Segundo Astrojildo Pereira, as bases partidárias eram formadas na sua maioria por operários ativistas do movimento sindical, e o partido se constituiu sobre uma firme base proletária. Seus estatutos dispunham que todo filiado devia "pertencer ao respectivo sindicato de indústria ou ofício, quando este exista" (art. $\left.3^{\circ}, c\right)$. Assim, desde o início, o partido deu grande importância à luta operária e sindical.

Logo após o congresso de fundação do PC do Brasil, os comunistas propuseram aos anarquistas a realização de um Primeiro de Maio unitário na praça Mauá, no Rio de Janeiro. A manifestação foi um relativo sucesso. Já em São Paulo — onde havia mais de um ano a Federação Operária deixara de existir —, o ato fracassou.

$\mathrm{O}$ ano de 1922 encerrou-se com um avanço do partido, que passou de $73 \mathrm{mem}$ bros na sua fundação para 250 filiados. A adesão ao partido de Octavio Brandão conhecido intelectual anarquista - foi um importante reforço. Ele passou a compor a Comissão Central Executiva e assumiu em abril de 1923 a tarefa de agitação e propaganda. Em maio daquele ano, o número de militantes se elevou para 300.

Em julho de 1923, a edição no 27 do jornal Voz Cosmopolita, do Centro Cosmopolita do Rio de Janeiro, iniciou a publicação — pioneira no Brasil — do Manifesto comunista, de Marx e Engels, em tradução do francês de Octavio Brandão. A publicação do Manifesto concluiu-se na edição nº 36, de dezembro de 1923. 


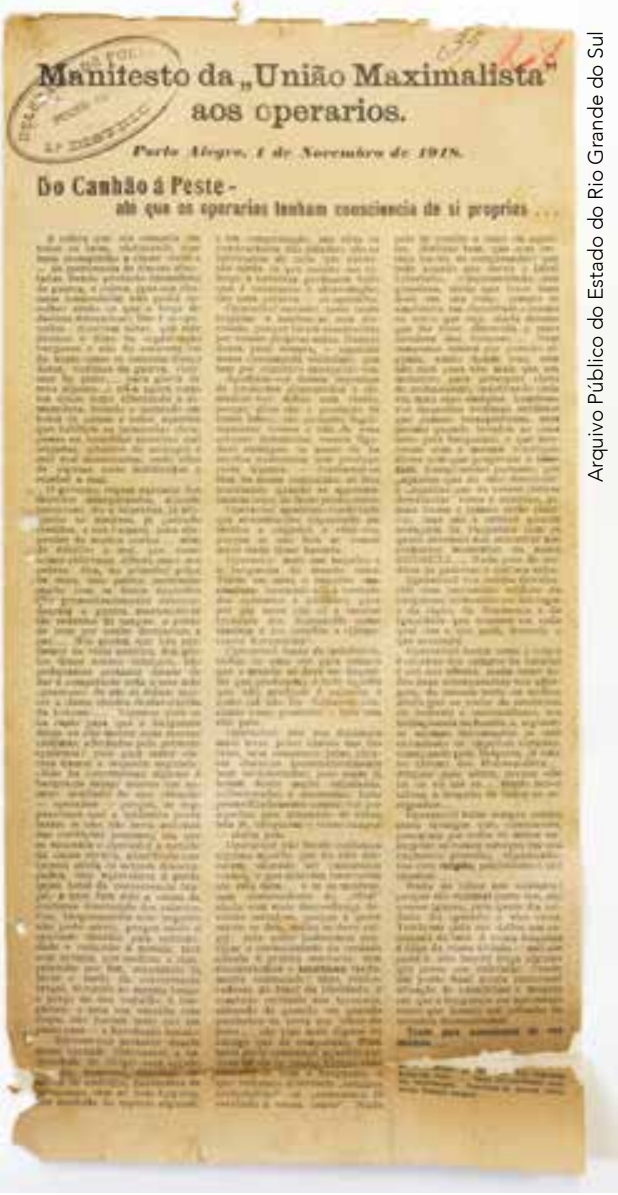

Camarada Romo

Sande

-

Gue farmula. sue minima. Gratto fulos vot

Op pimeiro Congremo communis te no Bravil, entón em verperas de re realigar, no Miso de gancieso, Será Recrets. Prora lá segui vir no 22 do cosrente, en rejeresentracer de nos

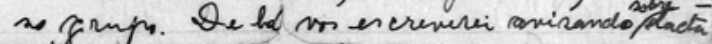

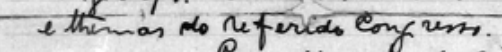

5 Caco disponth de sestatuto des eents connmunis 5 s, symdicatis e cooperativas fuira remettad-os ra min, a Travenca thermingurda ne 45-Meyer - Bis de Ganciro, guemos zeras Abraces com mumista

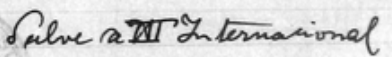

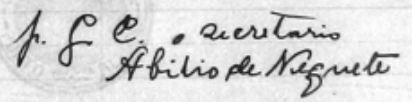
Porto Alyne, 20 de tamerins, V.

$\Delta$ Carta de Abílio de Nequete (fevereiro, 1922) pedindo ao "Camarada Romo" estatutos de organizações operárias para a formulação dos estatutos que seriam aprovados no $1^{\circ}$ Congresso do Partido Comunista do Brasil

4 Manifesto da União

Maximalista (novembro, 1918)

\section{MOVIMENTO COMMUNISTH}

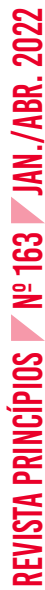

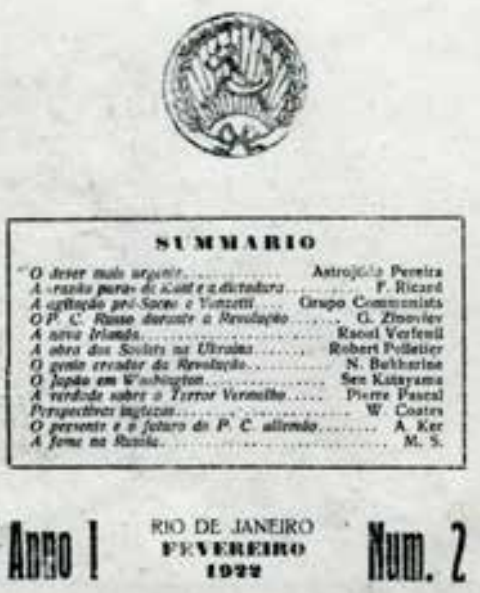

4 Capa da revista Movimento Communista, lançada em fevereiro de 1922. Em destaque, carimbo usado nas publicações do período; abaixo $\boldsymbol{\nabla}$, líderes anarquistas em 1919: Octavio

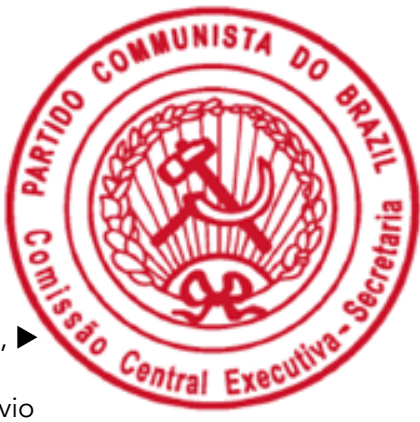
Brandão, Astrojildo Pereira e Afonso Schmidt (de pé), Edgar Leuenroth (de bigode) e Antonio Canellas

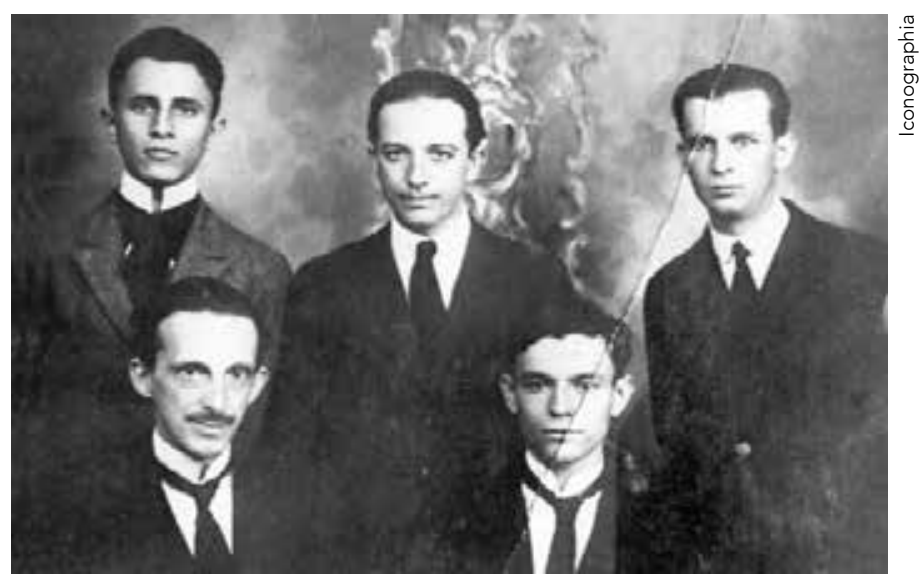


Ainda em 1923, os comunistas reorganizaram a desativada Federação dos Trabalhadores do Rio de Janeiro. Em resposta, os anarquistas criaram a Federação Operária do Rio de Janeiro, oficialmente "anarquista", cindindo o movimento operário carioca em duas federações:

A Federação dos Trabalhadores do Rio de Janeiro era débil. Os anarquistas e anarcossindicalistas cindiram-na. Criaram a Federação Operária com os sindicatos da construção civil, sapateiros e dissidentes do Centro Cosmopolita, num total de I.50o membros. A Federação dos Trabalhadores do Rio de Janeiro ficou com os sindicatos dos padeiros, alfaiates, carpinteiros, canteiros e marmoristas, e um total de 3.500 membros. [...] Esse fato provou como o anarquismo era cisionista [sic] e contribuiu para desmascará-lo (BRANDÃO, 1978, p. 250-25I).

Em 7 fevereiro de 1923, os gráficos de São Paulo iniciaram uma greve dirigida pelo comunista João da Costa Pimenta, secretário-geral da União dos Trabalhadores Gráficos de São Paulo. A greve foi maciça. Logo, os patrões de cinco grandes gráficas cederam. A greve continuou nas outras 40. A agitação operária se alastrou. A polícia prendeu Pimenta e o enviou para o Rio de Janeiro - sob estado de sítio - , para dificultar a sua libertação. Mas uma semana depois ele estava solto e de volta a São Paulo, a tempo de concluir de forma vitoriosa a greve. Em 22 de fevereiro, cerca 40 empresas já haviam acatado as exigências dos grevistas. A greve foi exitosa e fortaleceu os comunistas no movimento sindical.

No Primeiro de Maio de 1923, apesar do estado de sítio, os comunistas — em ampla articulação de sindicatos operários de várias tendências - conseguiram autorização da polícia para realizar um comício na praça Mauá, no Rio de Janeiro, com boa participação de trabalhadores. Na ocasião foram aprovadas moções pela unidade de ação da classe operária, contra o fascismo e contra as guerras imperialistas. Após essa mobilização do Primeiro de Maio de 1923 - na qual o partido teve forte protagonismo - a repressão recrudesceu:

Em maio e junho de 1923, a polícia política de Bernardes desencadeou a segunda perseguição ao PCB: prisões; buscas nos domicílios; interrogatórios, ameaças; acareações; a tipografia, no Méier, invadida; o depósito, com oito caixões e dois sacos cheios de livros, revistas, coleções do Movimento Comunista, tudo confiscado e destruído. Depois disso, as tipografias boicotaram o PCB. Em Santos e Cubatão houve prisões e perseguições. Em outubro de 1923, o governo Bernardes tratou de "legalizar" as ilegalidades. Sancionou uma lei contra a imprensa. Mais um obstáculo no caminho do PCB. A lei estabelecia a responsabilidade dos donos das tipografias. Estes, temendo as perseguições, recusavam imprimir os nossos materiais. [...] Em maio de 1923, pela terceira vez na vida, fui preso [...]. Fui acusado de organizar um complô na Marinha de Guerra, para derrubar Bernardes e estabelecer um governo "soviético". [...] Resisti. Desmascarei o provocador [...;] o processo, já iniciado, não pode ter andamento. Os presos [...] foram soltos. [...] Em junho de 1923, sob o mesmo governo Bernardes, fui preso, pela quarta vez (BRANDÃO, 1978, p. 246-248). 
À forte repressão policial somou-se uma dura polêmica com os anarquistas. Findas as ilusões de que os bolchevistas fossem anarquistas, estes iniciaram uma grande campanha contra os comunistas e a Revolução Russa. O jornal anarquista $A$ Plebe publicou um violento ataque a Lênin, quando de sua morte, em janeiro de I924, agravando ainda mais as relações entre anarquistas e comunistas:

Ele [Lênin] atualizou o aforismo jesuítico de que os fins justificam os meios. [...] Mussolini, na Itália, Primo de Rivera, na Espanha, e outros que esperam o momento oportuno para entrar em cena são os seguidores, os continuadores, os discípulos muito aplicados de suas teorias, de suas violências, sua falta de escrúpulos, seu ódio pela liberdade, sua dureza de coração e insensibilidade para com a dignidade do próximo. Ora, homens como esses são para nós duplamente prejudiciais: pelo mal que praticam e pelas ideias sinistras que espalham como justificação de sua conduta abominável. Lênin, mais do que qualquer outro déspota de todos os tempos, foi um desses homens sinistros (DULLES, 1977, p. 179).

No Rio Grande do Sul, o PC do Brasil procurou desenvolver o seu trabalho na classe operária, apesar dos duros ataques do anarcossindicalismo, que dirigia a Forgs: Autoritários, os anarcossindicalistas locais marcaram na paleta os pouquíssimos comunistas que tentaram alçar voo e cortaram suas asas. O primeiro jornal comunista que surgiu entre nós se chama Martelo e Foice, e data de 1924. [...] Perdeu-se pelas ruelas do Bom Fim, agarrado aos sonhos de Samuel Speisky, Eduardo Budaszewski, Henrique Scliar e outros. Mas os comunistas insistem, em 1924, [...] criam [... a] Associação dos Ofícios Vários. Através de Martelo e Foice, Samuel Speisky e Manoel Pereira acenam [...] aos operários metropolitanos, que continuam gravitando em torno dos militantes libertários encastelados nos "seus" sindicatos. De qualquer forma, essa associação é responsável por um fato pioneiro na história da esquerda brasileira: ela editou aqui, nesse ano, o Manifesto comunista, de Karl Marx. Fez-lhe uma edição de 3 mil exemplares, que custou 600 mil réis, segundo informa o tradutor, Octavio Brandão. Esse mesmo grupo publica, em I925, o livreto comunista Abre teus olhos, trabalhador, de Octavio Brandão, em alemão, tentando atrair ao menos uma fatia da classe operária porto-alegrense. A muralha anarquista, porém, é ainda impenetrável. Tão forte e tão intolerante que dois operários comunistas - Manoel Pereira e Francisco Januário Marques — são impedidos de participar do $3^{\circ}$ Congresso Operário Regional do Rio Grande do Sul, em setembro desse ano. Seu crime era pertencer a um partido político, o que foi denunciado em plenário [...; o PCB só se afirma aqui a partir de 1928, graças à moçada que sustentou o velho BOC — Bloco Operário e Camponês (MARÇAL, s.d.[b], p. 6-7).

\section{A historiadora Silvia Petersen também destaca a ação dos comunistas gaúchos:} sobre a presença comunista, sabe-se da existência em 1924 em Porto Alegre da União dos Ofícios Vários, que publicava o jornal Martelo e Foice - Hammer und Sichel, diri- 
Como se constata, o PC nasceu com o nome de Partido Comunista do Brasil, que conserva até hoje, não tendo registrado qualquer sigla. Depois de algum tempo, ficou conhecido como PCB. Em agosto de 1961 - quando o então Comitê Central criou o chamado Partido Comunista Brasileiro, os militantes e dirigentes que permaneceram fiéis ao partido de 1922 reorganizaram, em fevereiro de 1962, o Partido Comunista do Brasil, adotando a sigla PCdoB para se diferenciar do novo partido recém-criado. Ou seja, de 1922 a 1962, durante 40 anos, o Partido Comunista do Brasil foi conhecido pela sigla PCB. E de 1962 até os dias de hoje, por quase 60 anos, pela sigla PCdoB

gido por Manoel Pereira e H. Schondelmeyer, escrito em português e alemão e inspirado pelo Partido Comunista [...;] o Bloco Operário e Camponês (BOC), formado em I927, será o substituto principal do partido nas atividades públicas [...]. Na verdade, o anarquismo continuava sua lenta decadência no meio dos operários, e a hegemonia do PCB sobre o movimento sindical parece incontestável desde I927 (PETERSEN; LUCAS, I992, p. 304-305).

Em suas Memórias, Friedrich Kniestedt nos fala de outro jornal comunista publicado em alemão — o Die Befreiung (a libertação) —, anterior, portanto, ao Martelo e Foice:

Nos últimos meses de 1922 veio a Porto Alegre o primeiro representante do Partido Comunista [...,] o alfaiate F. Haberland, que tentou fazer propaganda de suas "novas" ideias na colônia alemã do Rio Grande do Sul. [...] Haberland veio até nós e juntamente com seus dois filhos foi admitido como membro do Sozialistischer Arbeiterverein [associação socialista de trabalhadores], onde [sic] os três participaram com muita dedicação. Mas muito logo nossos olhos se abriram. A Verein [associação] deveria adotar uma outra linha, mas sobretudo deveria ser ampliado [o] Der freie Arbeiter [o trabalhador livre]. Primeiro essa manobra foi tentada por bem, quando, porém, se viu 
que isso não era possível, que eu não o permitiria, aí se mostrou a verdadeira face [...;] todo o fichário dos endereços foi copiado, isto é, roubado, pelos filhos de Haberland. [...;] os três Haberlan foram expulsos da Verein [...]. Juntamente com alguns outros, Haberlan criou uma célula teutocomunista. [...] Der freie Arbeiter passou a sofrer concorrência. Haberland, Heffner e cia. passaram a editar Die Befreiung. Apareceram três números (GERTZ, I989, I35-I36).

Entre 27 de setembro e 2 de outubro de 1925 , realizou-se o $3^{\circ}$ Congresso Operário do Rio Grande do Sul, que mostrou como os anarquistas buscavam impedir os comunistas de participar das atividades sindicais:

\begin{abstract}
A mesa recebe a seguinte pergunta: "Podia um representante do jornal A Classe Operária, do Rio de Janeiro, tomar parte nos trabalhos do congresso?” Kniestedt responde que ficara assentado não poderem tomar parte do congresso delegados e representantes de organizações ou jornais que tivessem ligações com quaisquer partidos políticos. [...] Posto em aprovação se devia ou não tomar parte o representante de A Classe Operária, é deliberado que não. [...] Chegando nesse momento a delegação da União dos Operários Estivadores, desta capital, entrega a credencial apresentando, para tomarem parte no congresso, Francisco Januário Marques e Manoel Pereira. Kniestedt pergunta se a UOE fora convidada a tomar parte no congresso, sendo-lhe respondido que sim. O delegado da União dos Estivadores protesta contra a pergunta do representante do Der freie Arbeiter e este aparteia, declarando ter feito aquela pergunta porque conhece o delegado Manoel Pereira como militante de um partido político. [...] Manoel Pereira diz que [...,] quando se deseja sinceramente servir à causa da libertação do proletariado, não se deve afastar ou fugir de discutir todos e quaisquer assuntos (RODRIGUES, I979, p. 53-56).
\end{abstract}

\title{
14. A REBELIÃo MILITAR DE 1924, A COLUNA PRESTES E 0 2 CONGRESSO DO PARTIDO
}

Em 5 de julho de 1924, exatamente dois anos após o levante do Forte de Copacabana, eclodiu em São Paulo uma rebelião militar contra o governo Bernardes, comandada pelo general Isidoro Dias Lopes, à qual se somou a força pública estadual, comandada pelo major Miguel Costa. No dia 8, o governador se retirou de São Paulo e os rebeldes assumiram o controle da cidade. Levantes militares simultâneos ocorreram em Manaus e Sergipe, mas foram derrotados. Foi decretado o estado de sítio e o governo federal concentrou tropas, sitiando e bombardeando São Paulo. Após 22 dias do início da rebelião, os revoltosos tiveram de abandonar a cidade. Chefiados por Isidoro Lopes e Miguel Costa, 3 mil rebeldes seguiram de trem para a região de Foz do Iguaçu, no Paraná, onde se instalaram, resistindo aos ataques das forças legalistas.

A 24 de outubro de 1924, o capitão Luiz Carlos Prestes dirigiu um levante militar em Santo Ângelo, que se estendeu a toda a região missioneira do Rio Grande do Sul. Em fins de dezembro, à frente de I.50o homens, Prestes rompeu o cerco de 
São Luiz Gonzaga e se dirigiu, combatendo, para a região de Foz do Iguaçu, onde fez junção com as tropas de Isidoro. Lá chegou em II de abril de 1925, com 800 homens. Poucos dias antes, as tropas de Isidoro haviam sido derrotadas em Catanduvas. Em I4 de abril, teve início a lendária Coluna Prestes, que durante dois anos percorreu mais de 25 mil quilômetros pelo interior do país, atravessando I4 estados brasileiros, sem nunca ter sido derrotada. Miguel Costa foi o comandante da coluna, e Prestes, o seu chefe de Estado-Maior. Pretendiam semear a rebelião por onde passassem.

Em 4 de novembro de I924, ocorreu uma rebelião na Marinha. O primeiro-tenente Hercolino Cascardo sublevou o poderoso encouraçado São Paulo, mas, ao não obter adesões, zarpou para o Uruguai, onde abandonou o São Paulo e juntou-se aos militares rebelados no Rio Grande do Sul.

O estado de sítio devido à revolta e o feroz terror policial aprofundaram o refluxo em que já se encontrava o movimento operário desde I92I. Foi nesse contexto que os comunistas começaram a preparar o seu $2^{\circ}$ Congresso. Seguindo orientação da IC de criar bases por empresa, realizaram uma conferência de representantes das bases do partido nos sindicatos do Rio de Janeiro e Niterói:

Em meados de 1924, [houve] uma reunião ilegal no Centro Cosmopolita, a fim de examinar como se reorganizar sobre a base de células [...]. Mas, dias depois, rebentou a insurreição de São Paulo e a reorganização celular foi perturbada. O camarada Berezin, operário metalúrgico, israelita, era o encarregado dessa reorganização. Trabalhou bastante nesse sentido. Na segunda metade de 1924, saía do trabalho à tarde e ia diretamente às oficinas de São Diogo, da Estrada de Ferro Central do Brasil. Aí esteve mais de 30 vezes, até conquistar o primeiro ferroviário para o PCB [...; organizou a primeira célula do PCB na Marinha de Guerra, em 1924-I925 [...]. O PCB exercia influência sobre vários jornais: Voz Cosmopolita e O Alfaiate, no Rio de Janeiro. O Solidário, em Santos. Conquistou militantes nos sindicatos do Rio de Janeiro, em I923-I924: no Centro Cosmopolita, nos alfaiates, padeiros, sapateiros e construção civil (BRANDÃO, 1978, p. 249-250).

Em fevereiro de 1925, foi decidido criar o jornal de massas A Classe Operária - lançado no Primeiro de Maio desse ano - e organizar células do partido em todas grandes empresas industriais do Distrito Federal:

Naquele período havia no Rio de Janeiro 99 empresas com mais de cem operários cada uma, totalizando um número de 35.800 empregados. [...] Apesar da dificuldade da tarefa colocada, um ano depois ela havia sido cumprida no fundamental. Até setembro de 1925 haviam sido fundadas células nas fábricas do Rio de Janeiro, Recife, Vitória, São Paulo, Santos, Porto Alegre e outras cidades (KOVAL, I982, p. I87).

O $2^{\circ}$ Congresso do PC do Brasil ocorreu no Rio de Janeiro, de I6 a I8 de maio de 1925. Além dos membros da Comissão Central Executiva, participaram delegados das organizações do Rio de Janeiro e Niterói (cinco), Pernambuco (dois), Santos (dois), 
São Paulo (um) e Cubatão (um). A delegação do Rio Grande do Sul não participou por impossibilidade ocasional. A análise da realidade nacional se baseou essencialmente nas teses do livro Agrarismo e industrialismo, escrito por Octavio Brandão, que consideravam que as revoltas armadas de $\mathbf{1 9 2 2}$ e 1924 eram ações revolucionárias pequeno-burguesas que expressavam a contradição básica entre "o industrialismo e o agrarismo" e que haveria uma "terceira revolta", a qual os comunistas deveriam apoiar:

O defeito da concepção do agrarismo-industrialismo consistia em que ao proletariado atribuía-se, a priori, o limitado papel de força auxiliar [...]. Reconhecia-se antecipadamente que a burguesia industrial era o principal elemento atuante, proclamava-se que a forma principal de aliança era o "bloco do proletariado com a pequena burguesia industrial contra os plantadores de café" [...; o imperialismo norte-americano aparecia como força capaz de desempenhar papel positivo na industrialização do Brasil, na luta do "industrialismo" contra o "agrarismo" [...; ] ela levava à subordinação total dos interesses de classe do proletariado aos objetivos do movimento democrático de âmbito geral. No que se refere ao campesinato [..., seu papel era reconhecido apenas em palavras [...; ] ela condenava a classe operária à passividade e à espera inerte de que chegasse o momento de sua própria revolta [...; por um lado, fazia uma apreciação mais sensata do papel da pequena burguesia na luta revolucionária; por outro, exagerava o papel progressista da burguesia industrial e do capital norte-americano em sua luta contra a oligarquia rural [...; não levava em consideração a força revolucionária do campesinato, enquanto o proletariado perdia a qualidade de força motriz independente e mais progressista da revolução (KOVAL, I982, p. 19I-194).

As deficiências das teses do Partido Comunista do Brasil no seu $2^{\circ}$ Congresso nos mostram o pouco domínio que sua direção tinha do marxismo e da realidade brasileira. Mas também comprovam o esforço do partido em elaborar sua própria "teoria da revolução brasileira", desmentindo os que dizem que os comunistas brasileiros eram meros "repetidores das orientações de Moscou". Michel Zaidan Filho afirma corretamente que é falso atribuir à IC as formulações táticas e estratégicas do PC do Brasil em seus primeiros anos de vida:

Não haverá nada mais problemático, na história do PCB, que atribuir à sua linha política, durante os anos 20, uma mera sujeição burocrática às concepções da IC acerca da participação dos comunistas nos movimentos de libertação nacional em países coloniais e semicoloniais (ZAIDAN FILHO, 1988, p. 5I).

Além da orientação política geral, o $2^{\circ}$ Congresso expôs "o problema da unidade sindical como sendo a base, o centro, a condição mesma de desenvolvimento e fortalecimento da ação sindical de massas", aprovou a decisão da CCE de criar em I924 a Juventude Comunista e recomendou a formação de comitês de apoio e sustentação ao jornal A Classe Operária. 


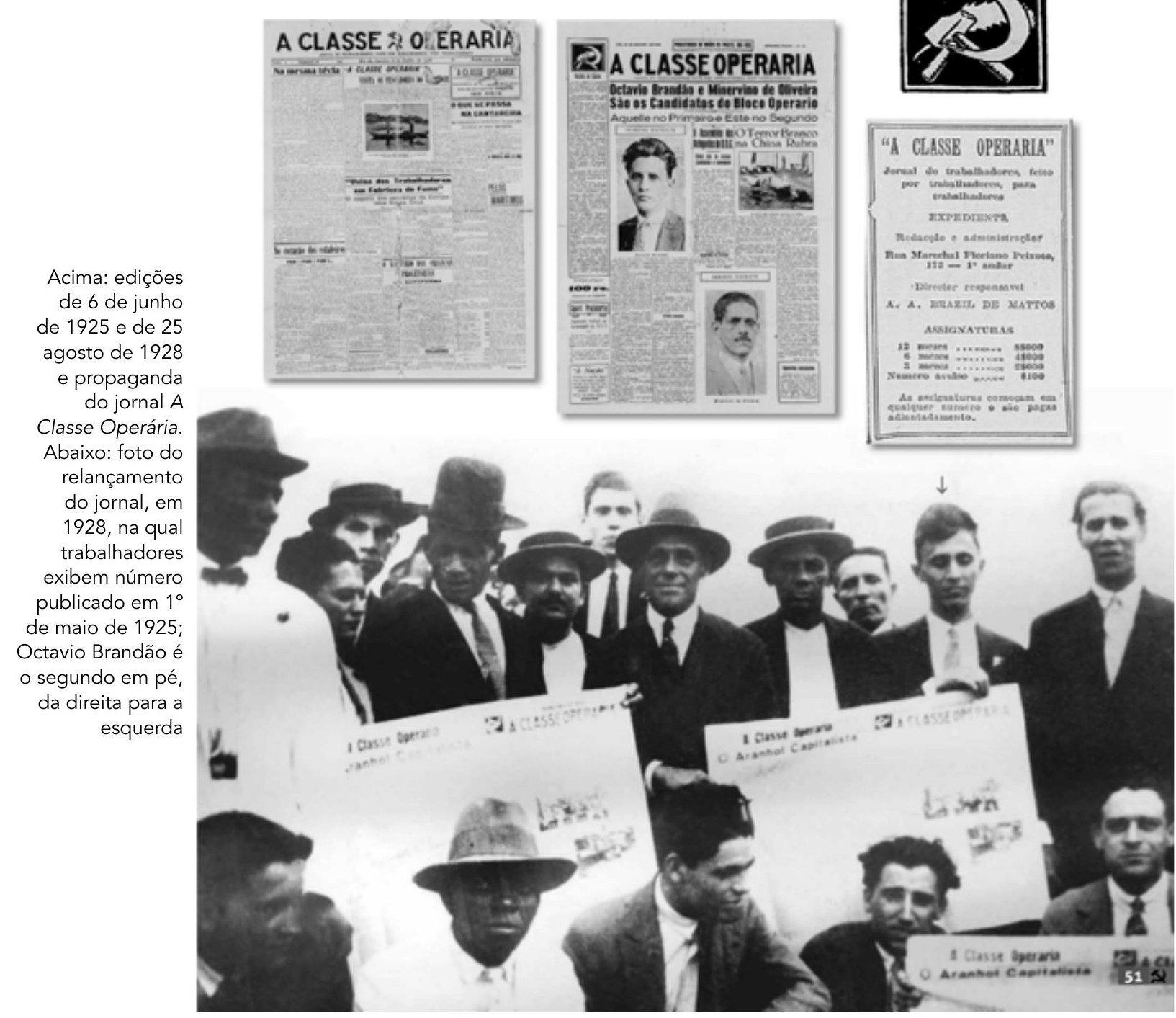

\section{O JORNAL A CLASSE OPERÁRIA E A PROPAGANDA DO PARTIDO}

Após o $2^{\circ}$ Congresso, os comunistas intensificaram consideravelmente o seu trabalho de agitação e propaganda entre as massas. Papel especial coube ao jornal $A$ Classe Operária, que sob o seu título anunciava: "Jornal de trabalhadores, feito por trabalhadores, para trabalhadores".

Seu primeiro número, em $\mathrm{I}^{\circ}$ de maio de 1925 , teve uma tiragem de 5 mil exemplares e se esgotou logo. A partir daí, o jornal foi ampliando a sua tiragem, atingindo 9.500 exemplares no seu $\mathrm{n}^{\circ} 9$ e il mil no $\mathrm{n}^{\circ}$ I2. Foram organizados comitês de $A$ Classe Operária e equipes de propagandistas e pacoteiros nas fábricas e oficinas. Grupos de operários doavam o salário equivalente a um dia de trabalho por mês para sustentá-lo, e alguns sindicatos aprovaram auxílios financeiros e realizavam mutirões para a venda do jornal nas principais fábricas:

Cada exemplar era lido por muitos trabalhadores. Passava de mão em mão, até ficar completamente roto, ilegível. Os operários que não podiam pagar recebiam-no de gra- 
ça. Representantes do jornal tomavam a palavra e eram apoiados nas assembleias dos sindicatos [...]. A Classe Operária exercia influência cada vez maior. Realizava um trabalho de educação e organização, agitação e propaganda. As células do PCB aumentavam. Os movimentos nas fábricas vivificavam-se. Os sindicatos reforçavam-se. [...] Rebentavam greves parciais apoiadas pelo jornal. [...] O jornal orientou-se no sentido da aliança do proletariado com os camponeses [...; no Rio de Janeiro, o jornal aparecia nas bancas, legalmente. Aí chegou a vender I.I42 exemplares do $n^{\circ} 4$, I.420 do no 9, I.454 do no Io e I.734 do $\mathrm{n}^{\circ}$ I2. Mas a grande maioria dos exemplares era distribuída pelos pacoteiros diretamente nas empresas (BRANDÃO, 1978, p. 306-309).

O governo não permitiu sequer três meses de liberdade para a imprensa comunista, e A Classe Operária foi fechada antes de publicar o seu n ${ }^{\circ}$ I3, previsto para 25 de julho de I925. Todas as tentativas de retomar a sua publicação falharam, pois as tipografias temiam represálias. Em novembro de 1925, o PC publicou o jornal 7 de Novembro para comemorar o oitavo aniversário da Revolução Russa, e em 2I de janeiro de I926, publicou o livro Wladimir Ilitch, para lembrar dois anos da morte de Lênin.

Apesar de todas as dificuldades, os comunistas fizeram ampla difusão de suas ideias. No artigo "La actividad del PCB", em La Correspondência Sudamericana, n 6, em I926, Octavio Brandão informa:

Até o fim de 1925 o partido distribuiu entre os trabalhadores 255 mil exemplares de diferentes materiais políticos; abriu curso de teoria marxista; organizou 30 semanas de estudos partidários, com 240 aulas, para I.440 alunos. A propaganda, incluída a da imprensa, alcançou 48 mil operários. Em 1926 foram distribuídos 3 mil exemplares do livro Wladimir Ilitch, com artigos de documentos de Lênin; grupos partidários comemoraram o dia da Comuna de Paris, o sétimo aniversário da Internacional Comunista e o do nascimento de Marx; o partido conseguiu editar 6 mil exemplares do boletim $I^{\circ}$ de Maio e organizar 20 exposições públicas dos materiais do $2^{\circ}$ Congresso. Foi criada a Federação da Juventude Comunista, que começou a difundir o seu órgão, O Jovem Proletário (SODRÉ, I984, p. 6I).

Só no Primeiro de Maio de 1928 A Classe Operária voltou a circular de forma semilegal. O símbolo do partido ostentava uma pena atravessada, e a tiragem passou a ser de 20 mil exemplares. A edição do Primeiro de Maio de 1929 - em formato grande, com I4 páginas - alcançou 30 mil exemplares. Outra edição, também em I929, atingiu 40 mil exemplares. Em meados de 1929, sua redação foi descoberta, invadida e destruída pela polícia. A partir de então, o partido publicou A Classe Operária de forma clandestina e teve diversas vezes as suas oficinas depredadas e os seus gráficos presos e torturados, até a conquista de sua legalidade, em I945.

Os comunistas também utilizaram outras publicações para difundir as suas idéias: Voz Cosmopolita e O Alfaiate, no Rio de Janeiro; O Maracajá, no Recife (1926); O Solidário, em Santos; Die Befreiung (a libertação, em alemão, 1923) e Martelo e Foice (bilíngue, em português e alemão, 1924) em Porto Alegre. Entre 1923 e I924, mantiveram uma coluna no diário $O$ País, do Rio de Janeiro. 


\title{
Aqui reside, inclusive, uma das particularidades históricas do PC do Brasil, que - diferentemente da maioria dos partidos comunistas, inclusive da América Latina - não surgiu de uma cisão ou da adesão à IC de algum partido social-democrata preexistente. Ao contrário, nasceu do movimento anarquista, em sua versão sindicalista revolucionária
}

Em fins de I925, o PC do Brasil propôs a formação de uma "frente única do proletariado" e a criação, no menor prazo possível, da Confederação Geral do Trabalho (CGT):

\begin{abstract}
A Classe Operária insistiu repetidamente na formação de uma grande frente única operária no Brasil [...; ] se bateu pela substituição dos "velhos" sindicatos de ofício pelos sindicatos de indústria. [...] Persuadiu os trabalhadores a se organizarem com um correspondente grau de centralização, para dar combate à "centralização cada dia maior do capitalismo" [...; o jornal se expressou assim: "A frente única não implica a renúncia a princípios de ordem doutrinária. Não chega a ser um acordo político, uma pacificação, sequer um armistício entre os que sustentam opiniões diferentes. [...] Quando se fala em frente única, é no terreno neutro, da luta econômica." (DULLES, 1977, p. 227, 244-245)
\end{abstract}

Os sindicatos deviam substituir a organização por ofícios pela organização por ramo industrial e formar federações por ramo industrial. Em 1926, os comunistas, organizados no Bloco Têxtil, derrotaram o sindicalista "amarelo" Pereira de Oliveira, na União dos Operários em Fábricas de Tecidos do Rio de Janeiro, com 83\% dos votos, dando importante passo para hegemonizar o movimento operário.

\section{A LUTA PARLAMENTAR, A JUVENTUDE COMUNISTA E A FORMAC̦̃̃O DA CGT}

Em sua primeira participação eleitoral, o PC lançou para o Conselho Municipal de Santos, em 1925, pela Coligação Operária, o garçom João Freire de Oliveira, que fez I,8\% dos votos, mas não se elegeu. Nas eleições municipais de i926, o dirigente comunista Joaquim Barboza de Souza foi, "a título pessoal", um dos oito nomes que compôs a chapa liberal no $\mathrm{I}^{\mathrm{o}}$ Distrito da capital federal, sem conseguir eleger-se. 
Em 3I de dezembro de 1926 expirou o prazo do estado de sítio, que não foi renovado. Com isso, a vida política do país voltou mais ou menos à normalidade e o partido - que nesse momento contava com cerca de 600 membros - voltou a ter, na prática, uma atuação legal.

Em fins de 1926, o jornalista Leônidas de Resende — dono do diário A Nação, que havia sido suspenso durante o governo Bernardes e que a partir da Revolução Russa se aproximara das ideias comunistas - propôs à direção do PC do Brasil retomar a publicação de $A$ Nação, como órgão do partido. Seu primeiro número, que saiu em 3 de janeiro de I927, ostentava a foice e o martelo, o dístico "Proletários de todos os países, uni-vos!", versos de "A Internacional” e frases de Lênin.

Em 5 de janeiro, A Nação publicou "Carta aberta da Comissão Central Executiva do PCB”, dirigida a várias organizações políticas operárias e líderes políticos, propondo a formação de um bloco operário para disputarem unidos as eleições para o Congresso Nacional, que se realizariam no dia 24 de fevereiro:

jamais o eleitorado operário do Brasil participou de uma campanha eleitoral nacional como força própria, como classe independente, apresentando um programa de reivindicações ditadas por seus interesses e aspirações de classe. [...] Os interesses e as aspirações do Partido Comunista não são diversos dos interesses e das aspirações do proletariado em geral. [...] É, pois, em nome da massa proletária, que o PCB se dirige, nesta carta aberta, às pessoas, aos partidos e aos centros acima mencionados [... e] propõe-lhes a formação de uma frente única proletária na campanha eleitoral iniciada, tomando para base uma plataforma única de combate, contendo as reivindicações mais elementares comuns às massas laboriosas em geral [...; ] a participação no pleito eleitoral de todos esses candidatos e partidos, concorrendo uns contra os outros, dispersivamente, só pode dar como resultado o enfraquecimento das forças operárias [....] não somente no terreno estritamente eleitoral, aritmético, do pleito, mas sobretudo enfraquecimento e dispersão no terreno político. [...] O Partido Comunista não pretende concorrer com candidatos próprios e de tal sorte dividir as forças operárias [...;] está disposto a apoiar a campanha eleitoral dos candidatos e demais grupos e partidos que aceitem travar a batalha em comum, na base de uma plataforma comum, segundo um plano comum (PEREIRA, 1976, p. III-II6).

Responderam favoravelmente à carta aberta o deputado Azevedo Lima, o Centro Político Proletário da Gávea e o Centro Político Proletário de Niterói. A "plataforma" proposta pelos comunistas é um documento que ainda hoje surpreende por sua atualidade. Algumas propostas foram incorporadas à legislação varguista, outras, à Constituição de I988, e outras ainda aguardam a sua efetivação:

Política independente de classe - [...] os candidatos do Bloco Operário tomam o prévio compromisso de subordinar sua atividade parlamentar ao controle da massa operária, cujo pensamento ouvirão, em cada ocasião, através de seus órgãos de classe autorizados. [...] 
Contra o imperialismo - [...] orientarão sua atividade no sentido da luta mais encarniçada contra o imperialismo das grandes potências financeiras. Dentro dessa orientação [...]: a) oposição a todo novo empréstimo externo; b) revisão dos contratos das empresas capitalistas estrangeiras concessionárias de serviços no Brasil; c) nacionalização das estradas de ferro, das minas e das usinas de energia elétrica; d) extinção das missões militar e naval estrangeiras; e) aliança com os países irmãos [...] que lutam contra os opressores imperialistas.

Reconhecimento de jure da URSS - [...] os candidatos do Bloco Operário preconizarão [...] o pleno restabelecimento das relações diplomáticas, comerciais e culturais entre os dois países.

Anistia aos presos políticos - Somos partidários da mais ampla anistia aos presos políticos de toda natureza, processados ou não, civis e militares. [...]

Legislação social - [...] Código do Trabalho [...; pontos principais da atividade parlamentar dos candidatos do Bloco Operário [...:] a) máximo de oito horas de trabalho diário e 44 horas semanais, e redução a 6 horas diárias nos trabalhos malsãos; b) proteção efetiva às mulheres operárias, aos menores operários, com a proibição do trabalho a menores de I4 anos; c) salário mínimo; d) contratos coletivos de trabalho; e) o seguro social [....] contra o desemprego, a invalidez, a enfermidade, a velhice; [...] g) licença, às operárias grávidas, de 60 dias antes e 60 dias depois do parto, com pagamento integral [...]; h) extinção dos serões [...]; i) descanso hebdomadário [dominical] em todos os ramos de trabalho [...; ...] m) saneamento rural [..., assistência médica gratuita aos doentes pobres [...].

Contra as leis de exceção - [...] pela mais completa liberdade de opinião, associação e reunião [...,] direito de greve [...,] proibir a indébita e arbitrária intervenção policial nas greves. [...] Os direitos de livre associação e livre opinião política devem ser extensivos aos pequenos funcionários e operários federais, estaduais e municipais [...].

Imposto - [...] só os ricos devem pagar impostos [...].

A reforma monetária e a carestia da vida — [...] a) reajustamento dos salários [...] segundo uma tabela [...] da relação entre o preço das utilidades e as necessidades mínimas da população trabalhadora [...,] impostos sobre o luxo, sobre as rendas e sobre o capital dos grandes senhores agrários, industriais e comerciais.

Habitação operária - [...] a) construção, expropriação e municipalização geral das casas para operários; b) aluguéis proporcionais aos salários [...]; c) supressão dos depósitos $[\ldots]$.

Ensino e educação - [...] a) pela ajuda econômica às crianças pobres [...]; b) pela multiplicação das escolas profissionais [...]; c) pela melhoria das condições de vida do professorado primário [...].

Voto secreto - Somos partidários do voto secreto e obrigatório, e extensivo às mulheres e às praças de pré, bem como aos operários estrangeiros com residência definitiva no país. Entendemos, porém, que o voto secreto e obrigatório não é a panaceia universal capaz de curar todos os males da democracia [...; ...] b) adoção do sistema de representação proporcional por quociente eleitoral (PEREIRA, I976, p. II6-I22). 
O Bloco Operário apoiou Azevedo Lima no $2^{\circ}$ Distrito e o gráfico João da Costa Pimenta no $\mathrm{I}^{\mathrm{o}}$ Distrito. Maurício de Lacerda, que não aderira ao Bloco Operário, foi candidato no $2^{\circ}$ Distrito e lançou Luiz Carlos Prestes no I $^{\circ}$ Distrito. Os comunistas o acusaram de estar tentando desviar a votação de João da Costa Pimenta, candidato dos operários. O diário A Nação assumiu o comando da campanha eleitoral, que teve grande repercussão. Abertas as urnas, no $\mathrm{I}^{\mathrm{o}}$ Distrito foram eleitos cinco situacionistas, o menos votado deles com 6.620 votos; Prestes obteve 3.I4I votos, e Pimenta, 2.024. Mesmo não tendo sido eleito, Pimenta teve votação considerável para a época e para a força real do partido. No $2^{\circ}$ Distrito, Maurício de Lacerda, com 5.202 votos, não se elegeu, mas os oposicionistas Adolfo Bergamini e Azevedo Lima lideraram a votação, com mais de II mil votos. O resultado foi uma grande vitória do Bloco Operário e do PC, que pela primeira vez passou a ter representação no Congresso Nacional:

Os efetivos do Bloco Operário na capital chegavam a 8.600 militantes. Esses militantes fizeram 232 conferências entre os operários, distribuíram 75 mil exemplares do programa do Bloco Operário [...]. Mais tarde, o Bloco Operário foi transformado em Bloco Operário e Camponês (KOVAL, 1982, p. 215-216).

Passadas as eleições, foi criada em abril de 1927 uma direção provisória para a Juventude Comunista, encabeçada por Leôncio Basbaum:

Criamos uma direção provisória com ajuda de alguns estudantes [...:] o Manuel [Karacick], o Francisco Mangabeira [...] e mais alguns que não demoraram muito em nosso movimento. Por sugestão nossa, A Nação publicava papeletas de inscrição para a JC [...; em poucos meses já havíamos recebido mais de cem inscrições, não somente do Rio, mas de outros estados [...]. Esses êxitos iniciais nos animaram a apressar a fundação da JC, que foi marcada para $\mathrm{I}^{\circ}$ de agosto [...; $90 \%$ dos membros da juventude comunista da época consistia[m] de jovens operários de 15 a I9 anos [...]. Começamos a editar um jornalzinho mimeografado, semanal, O Jovem Proletário. [...] Momentos agradáveis eu passava na redação de $A$ Nação [...]. Lá comparecia sempre [...] o Aporelly — Aparício Torelli -, um gaúcho que não pensava ainda que um dia passaria à nobreza com o título de Barão de Itararé (BASBAUM, 1976, p. 46-48).

Os comunistas realizaram, em abril de I927, o Congresso Sindical Regional do Rio de Janeiro, com a meta de unificar o movimento sindical. A Nação, que jogou papel decisivo na sua convocação, afirmou:

Duas tendências se debatem hoje em dia, no movimento sindical de todo o mundo. A tendência federalista, esposada pelos anarquistas e pelos anarcossindicalistas [....] vai cada vez mais perdendo terreno. A centralista é a que mais se impõe aos operários, como o meio mais eficaz de lutar contra a burguesia. Entre nós prevalecia, até bem pouco, o federalismo anárquico [...;] o resultado disso foi a dispersão de forças, a desagregação, e o estado de fraqueza em que se encontra o proletariado. A tendência centralista cada vez mais se impõe. Em vez de sindicatos de ofício, os sindicatos de indústria. Em vez de federações 
autônomas, as federações locais, federações nacionais de indústrias e, como remate, a CGT, organismo por excelência centralizado de todo o movimento sindical. Essa organização é a que mais consulta os interesses do proletariado na época atual de capitalismo centralizado, solidamente organizado (MUNAKATA, I984, p. 44-45).

Participaram do congresso 36 sindicatos, 23 comissões de fábrica e três "minorias revolucionárias", dos sindicatos contrários à unificação sindical. Dois anos depois, em abril de 1929 , foi criada a CGT.

No Primeiro de Maio, foi criada a Federação dos Trabalhadores Gráficos do Brasil, com delegados do Distrito Federal, Rio de Janeiro, Bahia, Paraíba, Pará, Amazonas, São Paulo e Minas Gerais, e foi realizado um grande comício em comemoração à data magna do trabalhador, na praça Mauá, convocado por A Nação.

Muitas outras campanhas foram feitas por A Nação - contra o fascismo, contra o imperialismo, contra a condenação de Sacco e Vanzetti, em defesa da URSS, em apoio à Revolução Chinesa etc.

Em um primeiro momento, a reação foi colhida de surpresa. Mas as classes dominantes não podiam tolerar a existência de um diário comunista, cuja influência crescia a olhos vistos. O governo enviou então ao Congresso a "Lei Celerada", que, além da repressão às greves, autorizava o fechamento de agremiações, sindicatos, centros ou entidades que praticassem "atos contrários à ordem", vedando a propaganda de suas ideias. A lei foi aprovada na Câmara dos Deputados no dia 28 de julho de I927. Antes que a lei fosse aprovada no Senado e sancionada, foi criado um regime de terror. Em $\mathrm{I}^{\mathrm{o}}$ de agosto, João Freire de Oliveira, gerente de $A$ Nação, recebeu voz de prisão, mas conseguiu fugir. No dia II de agosto, véspera da sanção pelo presidente da República, circulou o último número de $A$ Nação:

Jornal feito para as massas, destinando-se a larga repercussão no seio do proletariado nacional, é claro que $A$ Nação comunista só podia viver [...] como órgão legal do Partido Comunista. Desde, porém, que a mal disfarçada ditadura burguesa, armando-se de uma lei de exceção, coloca o partido fora da legalidade, este jornal perde sua razão de ser como órgão legal do comunismo. Seria quixotada completamente inócua esperar que a polícia venha fechar-nos as portas violentamente. Preferimos nós mesmos fechá-las — na cara da polícia. Declaramos portanto suspensa a publicação de $A$ Nação, a partir do próximo número (PEREIRA, I976, p. I05).

Sancionada a "Lei Celerada", o partido ficou em uma situação de semilegalidade. Com base na experiência exitosa do Bloco Operário, a direção partidária decidiu levá-lo para todo o país, utilizando-o como cobertura legal para sua atuação entre as massas. $\mathrm{O}$ Bloco Operário foi transformado em Bloco Operário e Camponês e organizado localmente, com estatutos e direções próprias, dirigidas pelo partido. O BOC se implantou rapidamente onde o partido existia. Através do BOC, os comunistas passaram a participar dos processos eleitorais estaduais e municipais e de diferentes atividades políticas e de massas: 


\section{Quanto ao chamado incidente do "cometa de Manchester" - passagem de um representante da IC por São Paulo, visando à organização do partido comunista no Brasil -, tudo indica ser uma "lenda fantasiosa", que contribuiu para essa imagem de "criação artificial” do partido}

Em princípios de 1928 [...] fui trabalhar no estaleiro Alcaraz \& Cia. [...; ] era ainda ajudante quando entrei em contato político com o caldeireiro Ramão, membro do Partido Comunista do Brasil. Ele começou a me tirar da cabeça algumas ideias anarquistas como o apoliticismo [...]. Num domingo, quando participávamos de um torneio de equipes operárias de várias empresas [...,] tomei parte de uma conversa com um moço, que depois de uma explanação política gentilmente nos ofereceu exemplares de A Classe Operária, jornal do PCB. Na segunda feira, Ramão, depois do almoço, manteve um diálogo comigo. Na próxima semana ingressei no Bloco Operário e Camponês. Na época, o novo militante só ingressava nas fileiras partidárias após certo tempo de comprovação da fidelidade à causa [...]. Aqui no Rio Grande do Sul, apesar da subestimação da atividade no campo, o BOC realizava um bom trabalho de organização e propaganda, defendendo as reivindicações imediatas dos trabalhadores em geral. [...] Em Porto Alegre, o BOC conseguiu influenciar vários setores da classe operária, sua sede social era na praça Parobé. Como membro da juventude dessa entidade, iniciei a tomar parte de uma organização de meu setor profissional, se não me falha a memória, era União dos Metalúrgicos (MARTINS, I989, p. 27-28, 34).

Em fevereiro de 1928, em São Paulo, o BOC lançou Nestor Pereira Júnior candidato à Assembleia Estadual. Ante as inúmeras arbitrariedades policiais contra sua campanha, o BOC paulista retirou a sua candidatura e apoiou os candidatos do Partido Democrático, contrariando a orientação do partido.

Em I $^{\mathrm{O}}$ de maio de $\mathbf{1 9 2 8}$, foi relançado o jornal A Classe Operária. Com o seu reaparecimento foi suspensa a publicação de $O$ Jovem Proletário, da JC, que havia circulado durante os quatro primeiros meses de 1928 com uma tiragem de cerca de mil exemplares. A Classe Operária continuou sendo um semanário até o final de 1929, calculando-se que nessa sua segunda fase sua tiragem normal foi de 15 mil exemplares.

Nas eleições municipais de outubro de I928, o BOC elegeu dois dos 24 conselheiros do Rio de Janeiro - o operário negro Minervino de Oliveira, no $2^{\circ}$ Distrito, com 7.692 votos, e o intelectual Octavio Brandão, no $\mathrm{I}^{\mathrm{o}}$ Distrito, com 7.088 votos. Minervino 
só tomou posse após uma dura luta contra uma tentativa de fraude. Em Santos, o BOC lançou João Freire de Oliveira, que não se elegeu, mas fez quase $5 \%$ dos votos dados. Na capital de São Paulo, o candidato foi Everardo Dias, que fez baixa votação. Em Porto Alegre, o BOC lançou no Io Distrito Plínio Gomes de Mello, que obteve 584 votos, mais de $5 \%$ dos votos, mas não foi eleito.

Após as eleições de 1928, o partido passou a não ter um controle absoluto sobre o BOC. A última participação eleitoral através dele ocorreu em 1930, quando os comunistas lançaram a candidatura de Minervino de Oliveira para a Presidência da República e de G. Valentim Antunes para a Vice-Presidência. Pouco depois o Bloco Operário e Camponês deixou de existir.

Nos seis primeiros anos de vida do partido, os comunistas acumularam importantes experiências. Derrotaram as concepções anarquistas no seio da classe operária, mas enfrentaram grandes dificuldades para arrancar os setores mais atrasados da classe operária da influência dos sindicatos reformistas. Participaram de importantes batalhas eleitorais e acumularam rica experiência de imprensa de massas. Tiveram poucos meses de vida legal e curtos períodos de semilegalidade. Mas não consolidaram um núcleo dirigente que dominasse o marxismo e conhecesse a realidade brasileira. Isso cobrou o seu tributo nos anos seguintes.

\section{CONCLUSÕES}

O surgimento do PC do Brasil decorreu, em primeiro lugar, da falência da anarcossindicalismo, que dirigiu as grandes lutas do proletariado brasileiro no final da década de Io do século passado - como as greves gerais de 1917 e I9I9 e a insurreição anarquista de I9ı — , levando-as a um beco sem saída. Nesse sentido, é herdeiro direto dessas grandes mobilizações operárias.

Aqui reside, inclusive, uma das particularidades históricas do PC do Brasil, que diferentemente da maioria dos partidos comunistas, inclusive da América Latina — não surgiu de uma cisão ou da adesão à IC de algum partido social-democrata preexistente. Ao contrário, nasceu do movimento anarquista, em sua versão sindicalista revolucionária:

O Partido Comunista do Brasil não será o resultado de uma cisão de um partido socialista, como fora o caso de vários outros partidos comunistas na América Latina (o da Argentina, em I9I8), principalmente depois do segundo congresso da Terceira Internacional, em 1920 (o do Chile, em I92I); nem da ação de militantes estrangeiros (como se passou no México, onde o partido foi fundado em I9I9 pelo indiano Manabendra Nath Roy) (PINHEIRO, I977, p. IO9).

Essa origem no anarcossindicalismo tem tanto as suas desvantagens - estreiteza, "apoliticismo", abstencionismo eleitoral, inexperiência organizativa - quanto as suas vantagens - combatividade, pregação da luta de classes, antirreformismo, internacionalismo. 
Em segundo lugar, o surgimento do PC do Brasil é o resultado natural do amadurecimento político das lideranças mais avançadas do movimento operário brasileiro de então, que - ao tomar conhecimento da Revolução Russa, das conquistas do poder soviético e da teoria marxista - perceberam a impotência do anarquismo, com o seu espontaneísmo, sua fluidez orgânica, seu “apoliticismo”. A Revolução Russa de outubro de I9I7 apresentou a eles, de forma clara, a questão da conquista do poder pela classe operária e a necessidade de um partido altamente organizado para dirigir a luta e de uma teoria e um programa revolucionários. É nesse sentido que se pode falar da enorme influência da Revolução Russa na formação do PC do Brasil, atuando como "catalisadora" desse processo de amadurecimento interno.

Essa compreensão sobre a grande influência da Revolução Russa no surgimento do PC do Brasil nada tem a ver com a opinião daqueles que afirmam que o PC do Brasil é uma criação artificial, fruto da ação da Internacional Comunista e de um punhado de "visionários" desligados do movimento operário brasileiro. Essa apreciação desqualificadora repete os surrados argumentos dos que enxergam o "dedo de Moscou" na origem dos partidos comunistas de todo o mundo.

Na verdade, a participação direta da IC no aparecimento do PC do Brasil é pequena, exercendo-se principalmente através do prestígio da Revolução de Outubro. Abílio Nequete, primeiro secretário-geral do partido, relata como tomou conhecimento, através do Partido Socialista Uruguaio, da convocação do $4^{\circ}$ Congresso da IC e do interesse de que o Brasil se fizesse presente através do seu partido comunista. A partir daí, Nequete manteve contato com os outros grupos comunistas do país, visando à convocação de um congresso de fundação do partido. Nesse Congresso, Nequete representará - além do grupo comunista de Porto Alegre - o PC do Uruguai e a Agência de Propaganda para a América do Sul da IC.

Quanto ao chamado incidente do "cometa de Manchester" - passagem de um representante da IC por São Paulo, visando à organização do partido comunista no Brasil —, tudo indica ser uma "lenda fantasiosa", que contribuiu para essa imagem de “criação artificial” do partido.

Nesse sentido, comprova-se a tese central deste estudo, que considera que a fundação do Partido Comunista do Brasil - independentemente de suas deficiências iniciais - foi um salto de qualidade na luta do proletariado brasileiro. E a sua persistência até os dias de hoje, apesar das terríveis perseguições, prova a sua necessidade histórica, que só desaparecerá com a supressão da sociedade de classes.

\footnotetext{
* Graduado em História pela Universidade Federal do Rio Grande do Sul (UFRGS), especialista em História Afro-Asiática pelas Faculdades PortoAlegrenses (Fapa). Presidente da Fundação Maurício Grabois no Rio Grande do Sul. Foi vereador de Porto Alegre em três legislaturas e deputado estadual em duas legislaturas, sempre pelo PCdoB. É autor, coautor e organizador de diversos livros e publicações.
} 
BANDEIRA, Luiz Alberto Moniz. $\mathbf{O}$ ano vermelho: a Revolução Russa e seus reflexos no Brasil. 2. ed. São Paulo: Brasiliense, 1980.

BARROS, Manoel de Souza et al. Memória e história. São Paulo: Lech, 1982. v. 2.

BASBAUM, Leôncio. Uma vida em seis tempos: memórias. São Paulo: Alfa-Omega, 1976.

BODEA, Miguel. A greve geral de 1917 e as origens do trabalhismo gaúcho. Porto Alegre: L\&PM, s.d.

BRANDÃO, Octavio. Combates e batalhas: memórias. São Paulo: Alfa-Omega, 1978. v. 1.

CARONE, Edgard. Algumas características do movimento operário no Brasil (1820-1914). Princípios, São Paulo, n. 41, cad. esp., 1996.

O PCB: 1922-1943. São Paulo: Difel, 1982. v. 1.

DIAS, Everardo. História das lutas sociais no Brasil. São Paulo: Edaglit, 1962.

DULLES, John W. F. Anarquistas e comunistas no Brasil (1900-1935). Rio de Janeiro: Nova Fronteira, 1977.

ENGELS, Friedrich. Carta a Sorge (29/11/1886). In: MARX, Karl; ENGELS, Friedrich. Correspondencia. Habana: Editora Política, 1988.

GERTZ, René E. Memórias de um imigrante anarquista. Porto Alegre: EST, 1989.

HARDMAN, Francisco Foot; LEONARDI, Victor. História da indústria e do trabalho no Brasil: das origens aos anos 20. 2. ed. São Paulo: Ática, 1991.

KOVAL, Boris. História do proletariado brasileiro: 1857 a 1967. São Paulo: Alfa-Omega, 1982.

LINHARES, Hermínio. Contribuição à história das lutas operárias no Brasil. 2. ed. São Paulo: Alfa-Omega, 1977.

. Movimento operário no Brasil. O Semanário, Rio de Janeiro, n. 150, 12-18 mar. 1959.

LÖWY, Michael et al. Introdução a uma história do movimento operário brasileiro no século XX. Belo Horizonte: Vega, 1980.

MARÇAL, João Batista. A primeira greve contra uma multinacional no RS. S.I.: mímeo, s.d.[a].

Comunistas gaúchos: a vida de 31 militantes da classe operária. Porto Alegre: Tchê!, 1986.

Os anarquistas no Rio Grande do Sul. Porto Alegre: Unidade Editorial, 1995.

Primeiras lutas operárias no Rio Grande do Sul. Porto Alegre: Livraria do Globo, 1985.

Reflexos da Revolução Russa no Rio Grande do Sul. S.I.: mímeo, s.d.[b].

MARTINS, Eloy. Um depoimento político: 55 anos de PCB. Porto Alegre: s.ed., 1989.

MARX, Karl; ENGELS, Friedrich. Contribuição para uma história da América Latina. São Paulo: Edições Populares, 1982.

MOREIRA, Aluizio Franco. A greve de 1917 em Recife. Clio, Recife, v. 23, n. 1, 2005.

MUNAKATA, Kazumi. A legislação trabalhista no Brasil. São Paulo: Brasiliense, 1984.

PARTIDO COMUNISTA DO BRASIL. 50 anos de luta. Rio de Janeiro: mímeo, 1972.

PEREIRA, Astrojildo. Formação do PCB: 1922-1928. Lisboa: Prelo, 1976.

PETERSEN, Silvia Regina Ferraz. As greves no Rio Grande do Sul (1890-1919). Porto Alegre: Mercado Aberto, 1979.

"Que a união operária seja a nossa pátria!": história das lutas dos operários gaúchos para

construir suas organizações. Santa Maria: Editora UFSM; Porto Alegre: Editora da UFRGS, 2001. 
; LUCAS, Maria Elizabeth. Antologia do movimento operário gaúcho: 1870-1937. Porto Alegre: Editora da UFRGS; Tchê!, 1992.

PINHEIRO, Paulo Sérgio. Política e trabalho no Brasil. 2. ed. Rio de Janeiro: Paz e Terra, 1977.

RODRIGUES, Edgar. Alvorada operária: os congressos operários no Brasil. Rio de Janeiro: Mundo Livre, 1979.

ROSITO, Renata Irene Haas. O pensamento político de Abílio de Nequete. Porto Alegre: PUC-RS, mímeo, 1972.

SEGATTO, José Antonio. A formação da classe operária no Brasil. Porto Alegre: Mercado Aberto, 1987.

SILVA JR., Adhemar Lourenço da. A greve geral de 1917 em Porto Alegre. Anos 90, Porto Alegre, v. 4, n. 5, p. 183-205, 1996.

SODRÉ, Nélson Werneck. Contribuição à história do PCB. São Paulo: Global, 1984.

ZAIDAN FILHO, Michel. O PCB e a Internacional Comunista (1922-1929). São Paulo: Vértice, 1988. 